ARChIWA - Kancelarie - ZBIORY

NR 3(5)/2012

Krzysztof Syta

Uniwersytet Mikotaja Kopernika w Toruniu

\title{
MATERIAŁY DO PRZEWODNIKA PO ARCHIWALIACH HETMANÓW KORONNYCH W ZASOBACH ARCHIWALNYCH I ZBIORACH BIBLIOTECZNYCH
}

Słowa kluczowe: archiwa hetmańskie, archiwalia hetmańskie, hetmaństwo koronne, dokumentacja hetmańska, wojskowość polska XVI-XVIII w., źródła archiwalne, archiwa rodzinno-majątkowe

ke y w o r d s: hetman's archives, royal hetmanship, hetman's records, Polish military $16^{\text {th }}$ $-18^{\text {th }}$ century, archival resources, private archives

Abstract

Tekst jest przeglądem materiałów archiwalnych pochodzących z archiwów hetmanów koronnych, przechowywanych obecnie w zasobach archiwalnych i zbiorach bibliotecznych na terenie Polski (Kraków, Kórnik, Łódź, Poznań, Warszawa) i Ukrainy (Kijów, Lwów). Publikacja nie jest przewodnikiem po archiwach hetmanów koronnych z okresu XVI-XVIII w., niemniej stanowi mocny fundament do stworzenia tego rodzaju pomocy archiwalnej. Przegląd zawiera charakterystykę różnych rodzajów archiwaliów, które autor uznał za integralnie związane ze sprawowaniem urzędów hetmańskich (akta osobiste, administracyjno-wojskowe, jurysdykcyjne, finansowe, korespondencja). Większość opisanych tu materiałów archiwalnych pochodzi z XVIII w, z archiwów następujących hetmanów koronnych: Jana Klemensa Branickiego, Franciszka Ksawerego Branickiego, Stanisława Mateusza, Wacława, Seweryna Rzewuskich i Adama Mikołaja Sieniawskiego. 
Dokumentacja urzędów hetmańskich od początku ich funkcjonowania nierozłącznie związana była z osobami je pełniącymi, a nie z nimi samymi ${ }^{1}$. W ten sposób znalazły one swoje miejsce w archiwach prywatnych najpierw hetmanów, a później ich spadkobierców ${ }^{2}$. Archiwalia hetmańskie nie były w nich traktowane jako wyjątkowo ważny i cenny fragment zasobu, może z wyjątkiem przywilejów nominacyjnych na urzędy hetmańskie, dokumentujących historyczną świetność rodziny czy rodu. Wynikało to ze specyfiki staropolskich archiwów prywatnych, w których najcenniejszą częścią zasobu były akta o charakterze prawno-majątkowym. Dopiero na przełomie XVIII i XIX wieku zaczęto dostrzegać historyczną wartość archiwaliów działalności publicznej, przechowywanych w archiwach prywatnych, co niewątpliwie miało pozytywne skutki również dla materiałów archiwalnych $\mathrm{z}$ archiwów hetmańskich. Jednak skomplikowane i różnorodne losy polskich archiwów prywatnych w okresie zaborów, a szczególnie I wojny światowej, odbiły się również i na zasobach archiwów hetmańskich, świadectwem czego jest obecny stan ich zachowania.

Przy dzisiejszym stopniu opracowania zasobów archiwalnych i zbiorów bibliotecznych nie jest możliwe idealne odtworzenie stanu zachowania archiwów hetmańskich. Przyczyn tego należy upatrywać pierwotnie w procesie ich archiwizacji. W przeważającej mierze dokumentacja w archiwach prywatnych w okresie staropolskim archiwizowała się w formie luzów, łączonych w wiązki i fascykuły, dużo rzadszą formą były tutaj księgi. Stan jej uporządkowania w archiwach bywał różnorodny. Należy uznać, że częściej nie było tam żadnego układu. Jednak w archiwach, których właściciele dbali o porządek ich zasobów, układ taki funkcjonował, ale podyktowany był celami pragmatycznymi. W związku z tym akta prawno-majątkowe ułożone były poszczególnym dobrami ziemskimi, do których się odnosiły. Pozostała część zasobu, w tym również dokumentacja proweniencji hetmańskiej, tworzyła bardziej lub mniej trafnie wydzielone grupy tematyczne. Bardziej zaawansowane prace nad porządkiem w archiwach prywatnych rozpoczęły się pod koniec XVIII i na początku XIX wieku. Między innymi w archiwum Branickich w Białymstoku oraz Rzewuskich w Podhorcach. Akcje te kończyły się w mniejszym lub większym stopniu nadaniem w archiwach porządku rzeczowego. Niestety, dzieje

${ }^{1}$ K. Syta, Dokumentacja wojskowa $w$ archiwach hetmanów koronnych, „Miscellanea Historico-Archivistica”, t. XIII, 2001 [druk 2002], s. 51-67.

${ }^{2}$ Tenże, Archiwa hetmanów koronnych. Pojęcie, charakter i typologia dokumentacji, „Archiwa - Kancelarie - Zbiory”, nr 2 (4), 2011, s. 63-105. 
archiwów, w czasie których nierzadko ich zasoby ulegały procesowi rozproszenie i niszczenia, wpłynęły na zatracenie pierwotnego porządku. Obecnie w archiwach państwowych zasoby archiwów prywatnych często udostępniane są na podstawie dawnych pomocy archiwalnych (np. Archiwum XX. Sanguszków w Krakowie). Niektóre z nich zostały uporządkowane po II wojnie światowej, wtedy, kiedy to w archiwach i bibliotekach państwowych masowo archiwizowano zbiory prywatnej dotychczas proweniencji. Jednak zarówno w pierwszym, jak i drugim przypadku system pomocy informacyjnych pozostawia wiele do życzenia. Gorzej rzecz przedstawia się w przypadku tych archiwaliów, które trafiły do zbiorów bibliotecznych. Najbardziej wyraźnym tego przykładem jest archiwum Sieniawskich, a później Czartoryskich w Bibliotece Czartoryskich w Krakowie. W XIX wieku akta zostały zszyte, przy tym w obrębie jednostek występują archiwalia bardzo różnorodne pod względem treści i formy. Tytuły tych jednostek też nierzadko pozostawiają wiele do życzenia np. varia, miscellanea, materiały historyczne, listy królewskie. W związku z tym dotarcie do akt urzędów hetmańskich, głównie w zbiorach bibliotecznych, niestety nierzadko ma charakter przypadkowy.

Informacje dotyczące archiwaliów ujętych w niniejszym opracowaniu zebrano w trakcie kwerendy przeprowadzonej kilkanaście lat temu (dlatego niektóre sygnatury podane w niniejszym zestawieniu są obecnie już nieaktualne). Objęto nią wówczas wszystkie instytucje, jakie przechowują archiwalia hetmańskie, ujęte głównie w ówczesnych pomocach informacyjnych. Spora część archiwaliów została jednak odnaleziona poza ówczesnym systemem informacji. Wśród archiwów objętych kwerendą znalazły się: Archiwum Główne Akt Dawnych w Warszawie (AGAD), Archiwum Państwowe w Krakowie (AP Kraków), Archiwum Państwowe w Łodzi (AP Łódź), Centralne Państwowe Historyczne Archiwum Ukrainy (CPHAU) w Kijowie i Lwowie. Spośród bibliotek kwerendą objęto: Bibliotekę Czartoryskich w Krakowie, Bibliotekę PAN w Krakowie, Bibliotekę PAN w Kórniku, Bibliotekę Zakładu Narodowego im. Ossolińskich we Wrocławiu, Bibliotekę Uniwersytetu Jagiellońskiego, Bibliotekę Uniwersytetu Warszawskiego, Bibliotekę Uniwersytetu im. I. Franko we Lwowie oraz Bibliotekę im. Stefanyka we Lwowie. Łączna liczba jednostek archiwalnych, które zostały wykorzystane do stworzenia niniejszego zestawienia, wynosi około 530.

Naturalnie niniejsze opracowanie swoją treścią nie wyczerpuje opisu wszystkich archiwaliów, którym można przypisać hetmańską proweniencję. Stanowi jednak mocny fundament do dalszej kwerendy, szczególnie w zaso- 


\section{Krzysztof Syta}

bach archiwów i bibliotek poza granicami naszego kraju. Większość zawartych w nim archiwaliów wytworzona została w wyniku działalności hetmanów XVIII-wiecznych. Z dużą dozą prawdopodobieństwa można założyć, że proporcji tych nie zmieni dalsza kwerenda. Szanse na odnalezienie większych fragmentów akt z zasobu archiwów hetmanów koronnych są niewielkie. A ta niezbyt optymistyczna konstatacja jest wynikiem dziejowego rozwoju urzędu hetmańskiego oraz magnackich archiwów. W dużej mierze potwierdzeniem tej tezy jest publikacja korespondencji hetmana polnego (1618-1632) i wielkiego (1632-1646) koronnego Stanisława Koniecpolskiego z 2005 r., opracowanej przez Agnieszkę Biedrzycką ${ }^{3}$. Autorka skrzętnie zbierając wszelkie źródła archiwalne, publikowane i niepublikowane, w zakresie listów, które narastały w archiwum Koniecpolskiego, dotarła do tych samych archiwaliów, do których trafił autor niniejszej publikacji w połowie lat 90. poprzedniego stulecia.

Opis stanu zachowania archiwaliów poszczególnych hetmanów został ujęty w formie swego rodzaju formularza o ujednoliconej strukturze, którą tworzą następujące poziomy: imię i nazwisko hetmana, nazwa instytucji, w której przechowywane są hetmańskie archiwalia, nazwa zespołu (ewentualnie zbioru), nazwa serii archiwaliów, sygnatura jednostki, jej zawartość. Pod pojęciem serii rozumieć należy jedną z grup dokumentacji występującej w hetmańskich archiwach, wydzieloną na podstawie kompetencji hetmańskich, to znaczy: administracyjno-wojskową, finansową, sądowniczą. Dodatkowo wydzielono korespondencję, dokumentację osobistą oraz dokumentację przybocznych oddziałów hetmańskich. Nie wyróżniono tutaj dokumentacji dyplomatycznej, gdyż zawiera się ona z reguły w korespondencji. Kolejność poszczególnych serii nie jest zachowana w opisie archiwaliów poszczególnych hetmanów, a podyktowane jest to jego przejrzystością. W przypadku, kiedy materiał w obrębie jednostki archiwalnej (bibliotecznej) jest jednorodny tematycznie, charakterystyka zawartości stanowi z reguły rozwinięcie jej tytułu. Jednak w większości przypadków materiał w obrębie poszczególnych jednostek jest różnorodny. Wówczas opis zawartości jest bardziej szczegółowy, nierzadko z odniesieniem do poszczególnych dokumentów.

3 A. Biedrzycka, Korespondencje Stanistawa Koniecpolskiego, hetmana wielkiego koronnego (1632-1646), Kraków 2005. 


\section{Archiwum Franciszka Ksawerego Branickiego}

AKTA OSOBISTE

\section{CPHA Kijów, fond 220}

sygn. 222 - przywilej Stanisława Augusta dla F. K. Branickiego i jego potomków na starostwo białocerkiewskie, Warszawa 13 grudnia 1774 r.

KORESPONDENCJA

AGAD, Archiwum Roskie,

pudło nr II, nr bieżący 69,

- P. Potocki, star. szczerzecki, z 1788 r.

AP Kraków, Archiwum Podhoreckie hr. Andrzeja Potockiego

- S. Rzewuski, het. pol. kor. z 1789 r. (sygn. I,1/5).

AP Kraków, Archiwum Potockich z Krzeszowic

sygn. 3228, Korespondencja różnych osób 1511-1821

- A. Lubomirski z 1792 r. (XXVII 3/23),

- A. Sapieha, kanc. wlk. lit. z 1792 r. (XXVII 3/26),

- W. Rzewuski, klan krak. z 1778 r. (XXVII 3/25),

- Zaleski, 3 listy z 1792 r. (XVII 3/28).

\section{Archiwum Jana Klemensa Branickiego}

AKTA ADMINISTRACYJNO-WOJSKOWE I SĄDOWNICZE

\section{AGAD, Archiwum Branickich z Rosi - militaria}

\section{Pudło nr 2}

- wyciągi z konstytucji sejmowych dotyczące spraw wojskowych, w tym urzędu hetmańskiego,

- regulaminy wojskowe,

- formularze różnych pism wystawianych przez hetmana i króla,

- postulaty w sprawie uprawnień het. pol. kor. przygotowane przez Wacława Rzewuskiego oraz replika na nie (kopie), 
- różnego rodzaju zestawienia wojsk począwszy od 1717 r. (m.in. rejestr wyższych oficerów w wojsku koronnym),

- kopie i oryginały patentów i ordynansów przedstawionych do forsztelacji J. K. Branickiego,

- akta spraw finansowych, m.in. postanowienia komisji skarbowej wojskowej, rachunki i asygnacje podskarbich wielkich koronnych związane z pensją hetmańską J. K. Branickiego z lat 1736-1760 i b.d. Akta związane $\mathrm{z}$ wybieraniem egzakcji z poszczególnych województw z lat 1740-1772, zestawienia retent poszczególnych województw i ziem z lat 1750-1773. Regestry wydatków na reparację broni, lenungi i gaże oficerskie z lat 1735-1771.

\section{Pudło nr 3}

plik 5 - akta dotyczące sądownictwa wojskowego

- zestawienia składu sądu wojskowego na Komisji Radomskiej w latach 1737-1760,

- wykaz wojskowych pełniących funkcje poselskie i komisarskie w latach 1757-1758,

- postulaty wojska koronnego przedstawione podczas posiedzeń Trybunału Skarbowego Koronnego w Radomiu z 20.05.1760 r.,

- dekrety sądów wojskowych z lat 1752-1762,

- akta spraw rozpatrywanych przez sądy wojskowe w latach 1754-1770 (pozwy, inkwizycje, dekrety).

\section{Pudło nr 4}

plik 1

- memoriały, dezyderaty, prośby, petycje i supliki kierowane do J. K. Branickiego w różnych sprawach wojskowych w latach 1752-1759. Tutaj między innymi prośba oficerów regimentu artylerii koronnej z Kamieńca z 12.03.1752 r. o niepomijanie ich w awansach (CXLVIII 3/96) oraz desideria garnizonów pogranicznych i ich komendanta gen. lejtnanta Potockiego z 02.02.1756 r. w sprawie wzmocnienia załóg i organizacji obrony (CXLIX 1/8),

- instrukcje, raporty i inne pisma wojskowe. Tutaj m.in. kopia instrukcji danej posłom wojskowym na sejm grodzieński w 1752 r. oraz instrukcja dana posłom województwa podolskiego do J. K. Branickiego w sprawie utworzenia milicji krajowej z 01.03.1757 r. (CLXXI/41), 
- listy różnych do różnych w sprawach wojskowych (oryginalne i kopie). plik 2

- akta dotyczące spraw pogranicznych (oryginały i kopie), pochodzące w większości z ekspedycji cudzoziemskiej z kancelarii J. K. Branickiego. Tutaj m. in. akta działalności sądów pogranicznych, głównie polsko-tatarskich i polsko-rosyjskich, akta różnego rodzaju komisji rozjemczych, korespondencja (kopie i oryginały) w sprawach polityczno-wojskowych między przedstawicielami Rzeczypospolitej i państw sąsiednich.

\section{Pudło nr 5 - Regiment Pieszy Gwardii Koronnej}

plik 4

- lista oficerów sztabowych i wyższych regimentu sporządzona podczas rewizji przeprowadzonej przez generała K. Granowskiego 17.09.1779 r., plik 5

- lista żołnierzy regimentu, którzy podczas ww. rewizji byli niezdolni do służby,

plik 6

- tabele generalne (miesięczne) od regimentu z lat 1752-1763 (w obrębie roczników niekompletne),

- abszyt wystawiony przez A. Czartoryskiego w 1781 r. dla żołnierza Kilimona Kierpowicza,

plik $7-8$

- akta spraw spornych i procesowych żołnierzy regimentu. Między innymi kopia sekcji i obdukcji zwłok kapitana Raaby (w języku niemieckim), sprawa toczona przed sądem hetmańskim przeciwko kapitanowi Janowi Lyzandrowi z powództwa władz miasta Lublina (z lat 1761-1762), kopie umów zawartych przez gen. majora wojsk kor. Fleminga $\mathrm{z}$ regimentem w $1743 \mathrm{r}$.,

plik 9

- sztam i grundlisty poszczególnych kompanii regimentu spisane podczas rewizji przeprowadzonej przez gen. wojska kor. K. Granowskiego w dniach 18-20 maja 1759 r. (21 poszytów).

\section{Pudło nr 6 - Regiment Pieszy Najjaśniejszej Królowej i Rzeczypospolitej} plik 1

- Regulamin Generalny regimentu, 
plik 2

- tabele i raporty tabelaryczne od regimentu (bądź jego poszczególnych kompanii) z roku: 1751 (maj-sierpień, październik-listopad), 1752 (październik-grudzień), 1753 (styczeń-luty, kwiecień-maj, lipiec-grudzień), 1754 (styczeń-luty, kwiecień, lipiec, listopad-grudzień), 1755 (styczeń, marzec-czerwiec, sierpień-październik, grudzień), 1756 (luty-czerwiec, sierpień-grudzień), 1757 (styczeń-sierpień, wrzesień-październik), 1758 (marzec-kwiecień, lipiec, wrzesień-grudzień), 1759 (styczeń-sierpień, październik-grudzień), 1760 (styczeń-kwiecień, wrzesień-grudzień), 1761 (styczeń-sierpień, październik, grudzień), 1762 (styczeń-październik), 1763 (luty-czerwiec, wrzesień), 1766 (grudzień), 1767 (luty, kwiecień), 1768 (styczeń-luty, kwiecień, lipiec, wrzesień-grudzień), 1769 (styczeń, marzec, czerwiec, sierpień-wrzesień), 1770 (wrzesień), 1771 (styczeń-luty, kwiecień-lipiec). Tutaj dodatkowo 2 tabele b.d. od 1. i 2. batalionu ww. regimentu. Raporty wysyłane były z: Elbląga (najczęściej podpisane przez płk. Jana de Reinholda), Mościsk (Jan Kasper Pflantz i August Stanisław Goltz), z Kamieńca (płk. Józef Biernowski).

Dodatkowo w pudle 7 (plik 1) znajdują się omyłkowo umieszczone tabele Regimentu Pieszego Najjaśniejszej Królowej i Rzeczypospolitej z garnizonu elbląskiego za miesiąc kwiecień 1756 r. i grudzień 1757 r.,

plik 3

- kopia listu płk. J. Biernowskiego do gen. lejtnanta Potockiego,

- pismo służbowe Jana Kaspra Pflantza,

plik 4

- ranglista sztabowych i wyższych oficerów regimentu (3 sztuki z: 21 lutego 1752, 1 lutego 1759, 1 lutego 1762),

plik 5

- petycje złożone na ręce J. K. Branickiego przez żołnierzy i oficerów regimentu ( 3 sztuki z lat: 1751, 1761),

plik 6

- akta w sprawach regimentu z okresu po śmierci J. K. Branickiego, plik 7

- akta związane z finansami regimentu. Między innymi widymat rewersu zaciągniętej pożyczki przez płk. Jana de Reinholda od burmistrza Elbląga na potrzeby regimentu z 9 sierpnia 1752 roku, stan kasy regimentowej w roku 1762, 
plik 8

- akta spraw spornych i procesowych z udziałem żołnierzy regimentu $\mathrm{z}$ lat 1743-1785 (umowy, protestacje, orzeczenia, memoriały, indagacje, dekrety).

Dodatkowo w pudle 10 (plik 8) znajduje się poszyt zawierający zapis dochodzenia w sprawie długów zmarłego płk. Jana de Reinholda, komendanta regimentu, przeprowadzonego na polecenie J. K. Branickiego przez mjra Blocka w Elblągu, w lutym 1758 r.,

plik 9

- akta dotyczące sprawy wkroczenia wojsk rosyjskich do Elbląga w marcu 1758 r., gdzie stacjonowała część regimentu (między innymi: inkwizycje i memoriał).

\section{Pudło nr 7 - Regiment Pieszy Królewicza i Rzeczypospolitej}

plik 1

- tabele miesięczne i raporty generalne regimentu, jego poszczególnych kompanii i batalionów z lat: 1751 (maj-grudzień), 1752 (styczeń kwiecień, czerwiec-wrzesień, listopad),1753 (styczeń-grudzień), 1754 (styczeń-grudzień), 1755 (styczeń, maj-październik), 1756 (styczeń-czerwiec, sierpień-październik, grudzień), 1757 (styczeń, marzec-czerwiec, sierpień-listopad), 1758 (marzec, czerwiec, sierpień, październik-grudzień), 1759 (styczeń-grudzień), 1760 (styczeń-marzec, wrzesień-październik, grudzień), 1761 (styczeń-maj, sierpień-październik, grudzień), 1762 (styczeń-sierpień, październik, grudzień), 1763 (luty-kwiecień, czerwiec-wrzesień), 1767 (luty, kwiecień, grudzień), 1768 (styczeń-marzec, maj, lipiec-wrzesień, grudzień), 1769 (styczeń, grudzień), 1771 (kwiecień, czerwiec-lipiec). Dodatkowo 2 tabele b.d.

Miejscem wysyłania raportów były następujące miejscowości: Dubno, Elbląg, Kamieniec Podolski, Kraków, Poznań, Radom, Tyczyn. W pliku tym omyłkowo umieszczono również tabele regimentu pieszego Najjaśniejszej Królowej i Rzeczypospolitej z garnizonu elbląskiego za miesiąc kwiecień 1756 r. i grudzień 1757 r.,

plik 2

- akta związane z nominacjami porucznikowskimi w regimencie. Między innymi kopia patentu porucznikowskiego wydanego I. Jankowskiemu 12 maja 1749 roku przez gen. J. W. Goltza oraz oryginał paten- 
tu porucznikowskiego dla Przyciszewskiego z 26 sierpnia 1755 r. Tutaj także niepodpisany ordynans J. K. Branickiego do płk. Jana de Reinholda w sprawie forsztelacji Przyciszewskiego na stopień porucznika, plik 3

- akta dotyczące spraw spornych i procesowych z udziałem żołnierzy regimentu. Między innymi akta sprawy z lat 1751-1752 pomiędzy gen. majorem Goltzem, komendantem regimentu, a obersterlejtnantem S. Sułkowskim, dowódcą jego 2 batalionu. Tutaj także sprawa sądowa przeciwko S. Sułkowskiemu o popełnione przestępstwa w Kamieńcu z roku 1760 (ordynans J. K. Branickiego dla gen. majora Szultza nakazujący przeprowadzenie śledztwa oraz prezydowania w sądzie wojskowym).

Tutaj przypadkowo również akta sprawy sądowej porucznika Regimentu Pieszego Najjaśniejszej Królowej i Rzeczypospolitej z 1757 r.

\section{Pudło nr 8 - Regiment Pieszy Łanowy}

plik 1

- akta dotyczące organizacji regimentu, głównie związane z jego sprawami finansowymi,

plik 2

- regulamin regimentu z 1 stycznia 1753 r., plik 3

- tabele miesięczne i raporty regimentu z lat: 1750 (luty, wrzesień), 1751 (kwiecień-sierpień, październik, grudzień), 1752 (styczeń-luty, czerwiec, wrzesień, listopad-grudzień), 1753 (styczeń-luty, kwiecieńczerwiec, sierpień-grudzień), 1754 (styczeń-marzec, maj-wrzesień), 1755 (styczeń, czerwiec, sierpień-grudzień), 1756 (luty, kwiecień-maj, sierpień-wrzesień), 1757 (styczeń, kwiecień-czerwiec, wrzesień-październik), 1758 (marzec-kwiecień, lipiec-sierpień, październik-grudzień), 1759 (styczeń-czerwiec, sierpień, listopad-grudzień), 1760 (styczeń-marzec, wrzesień-październik, grudzień), 1761 (styczeń-luty, kwiecień-maj, wrzesień, grudzień), 1762 (styczeń, marzec-czerwiec, sierpień-wrzesień, grudzień), 1763 ( luty-maj, lipiec, wrzesień), 1767 (marzec-maj, sierpień, listopad), 1768 (styczeń-kwiecień, czerwiec-październik, grudzień), 1769 (styczeń-luty), 1770 (luty),

- lista oficerów sztabowych i wyższych regimentu z 24 lipca $1771 \mathrm{r}$. 
Tutaj także omyłkowo miesięczna tabela garnizonu lwowskiego $\mathrm{z}$ roku 1758.

plik 4

- rolla ludzi od komendy regimentu z Kamieńca Podolskiego, z 1 stycznia 1750 r.,

plik 5

- kopie dwóch ordynansów wydanych przez komendanta i szefa regimentu łanowego A. Kossowskiego w 1752 r.,

- egzempt (usprawiedliwienie) wydane przez J. K. Branickiego dla kpt. regimentu A. Montayma,

plik 6

- akta dotyczące nominacji na stopnie oficerskie w regimencie. Między innymi oblata patentu na pułkownikostwo dla I. Podoskiego oraz niepodpisany patent na szarżę majora dla Kietlińskiego,

plik 7

- akta spraw spornych i procesowych z udziałem żołnierzy regimentu (oblaty ugody zawartej pomiędzy oficerami a żołnierzami regimentu z lat 1732, 1753, 1756).

\section{Pudło nr 9 - Regiment Pieszy Artylerii Koronnej}

plik 1

- akta związane z organizacją regimentu. Tutaj zalecenia pokontrolne wydane przez generalnego inspektora wojsk kor. K. Granowskiego podczas rewizji regimentu w dniu 6 września $1761 \mathrm{r}$. oraz instrukcja w sprawie przesyłania kwartalnych raportów od regimentu do hetmana wielkiego koronnego,

plik 2

- tabele miesięczne i raporty regimentu z lat: 1735 (maj). 1736 (kwiecień), 1751 (kwiecień-sierpień, październik-listopad), 1752 (styczeń-luty, kwiecień, czerwiec-lipiec, wrzesień-listopad), 1753 (kwiecień-grudzień), 1754 (styczeń-grudzień), 1755 (styczeń-luty, kwiecień-lipiec, wrzesień-październik, grudzień), 1756 (styczeń-grudzień), 1757 (styczeń-grudzień), 1758 (marzec-kwiecień, czerwiec-lipiec, wrzesień-grudzień), 1759 ( styczeń-marzec, lipiec, wrzesień), 1760 (styczeń-marzec, wrzesień-grudzień), 1761 (styczeń-luty, kwiecień-lipiec, wrzesień, grudzień), 1762 (styczeń-lipiec, wrzesień, grudzień), 1763 (luty-lipiec, wrzesień-październik), 1767 (luty, kwiecień-maj, listo- 
pad-grudzień), 1768 (styczeń-sierpień, październik-grudzień), 1769 (marzec-grudzień), 1770 (styczeń-luty).

Raporty wysyłane były z: Bydgoszczy, Kamieńca, Krakowa. plik 3

- 2 raporty dotyczące stanu osobowego regimentu. Pierwszy od komendanta regimentu Bruhla z 3 grudnia 1754 r., drugi z 7 lipca 1759 r. zawiera zestawienie żołnierzy kompanii Joachima Potockiego, plik 4

- tabele różnego rodzaju dotyczące stanu osobowego poszczególnych pododdziałów regimentu. Między innymi od untersztabu, leibkompanii i poszczególnych kompanii. Tutaj także zestawienie kadetów znajdujących się przy regimencie oraz lista inwalidów biorących żołd z kasy regimentowej. Wszystkie akta sporządzono podczas rewizji regimentu na przełomie sierpnia i września 1761 roku.

plik 5

- akta dotyczące poszczególnych żołnierzy regimentu. Tutaj kopia patentu dla por. Odrzywolskiego na szarżę kapitana z 1747 r. oraz akta w sprawie kwatery por. Rottermunda w Krakowie z roku 1761, plik 6

- akta finansowe regimentu. Likwidacja regimentu na Trybunale Skarbowym radomskim za okres 01.05.1755-10.04.1756,

plik 7

- akta spraw spornych i procesowych z udziałem żołnierzy regimentu z lat 1740-1762. Między innymi: pozwy, inkwizycje, repliki stron, memoriały, dekrety różnych sądów (wojskowych, grodzkich, Trybunału Skarbowego w Radomiu).

\section{Pudło nr 10 - Regiment Pieszy Buławy Wielkiej Koronnej}

plik 1

- kopie ordynansów i instrukcji wydanych przez Augusta Czartoryskiego, regimentarza wojska koronnego oraz Komisję Wojskową dla regimentu w latach 1764-1768. Tutaj także kopia memoriału do J. K. Branickiego od mjra Komorowskiego w sprawie osobistej i żołnierzy regimentu z 04.12.1752 r.,

plik 2

- tabele i raporty miesięczne od regimentu z lat: 1751 (wrzesień-grudzień), 1752 (styczeń-marzec, maj-lipiec), 1753 (kwiecień, czerwiec, 
sierpień-grudzień), 1754 (styczeń, marzec-maj, lipiec), 1755 (wrzesień), 1756 (styczeń-luty, sierpień, grudzień), 1757 (marzec-kwiecień, październik, grudzień), 1758 (styczeń-lipiec, wrzesień-grudzień), 1759 (styczeń-sierpień, październik-grudzień), 1760 (styczeń-maj, sierpień-październik, grudzień), 1761 (luty-sierpień, październik-grudzień), 1762 (styczeń-lipiec, grudzień), 1763 (styczeń-wrzesień), 1764 (październik-listopad), 1765 (grudzień), 1766 (luty-lipiec, wrzesień-grudzień), 1767 (luty-maj, sierpień, grudzień), 1768 (styczeń-luty, kwiecień-lipiec, wrzesień, listopad-grudzień), 1769 (luty-czerwiec, sierpień, październik, grudzień), 1770 (styczeń-luty), 1771 (luty, kwiecień-lipiec),

plik 3

- zestawienia oficerów sztabowych i wyższych regimentu z: 23 sierpnia 1758, 12 kwietnia 1760, 6 i 7 maja 1767, 6 lutego 1771 r. Tutaj także zestawienie kadetów służących w regimencie z garnizonu lwowskiego z 13 maja 1761 r.,

plik 4

- akta dotyczące spraw finansowych regimentu z lat 1750 1761. Między innymi zestawienia podatków poszczególnych powiatów, jakie powinny wpłacić one na rzecz regimentu, rachunki poborców regimentowych z wybranych podatków oraz ich rozchodu,

plik 5

- akta finansowe regimentu. Znajduje się tutaj 5 poszytów zawierających zestawienia należności regimentu za lata 1752-1761 uchwalone podczas posiedzeń Trybunału Skarbowego w Radomiu,

plik 6

- akta finansowe regimentu. Między innymi znajdują się tutaj listy płac oficerów regimentu z lat 1760-1767 oraz wydatki z pensji J. K. Branickiego jako szefa regimentu,

plik 7

- ordynanse i dyspozycje J. K. Branickiego w sprawach finansowych regimentu. Są to w większości polecenia wydane kasie regimentu w celu rozdziału wakujących porcji na gaże pomiędzy jego żołnierzy. Tutaj także polecenia do poborców regimentowych, aby wypłacali z wybranych retent przeznaczonych na pensję dla Branickiego należności różnym osobom, między innymi kupcom, 
plik 8

- akta finansowe regimentu. Tutaj rachunki przychodu i rozchodu prowadzone przez kasę regimentową,

plik 9

- akta finansowe regimentu. Tutaj znajdują się różnego rodzaju pokwitowania oficerów regimentu z pobranych gaż oficerskich oraz lenungów (pensji żołnierskich),

plik 10

- akta finansowe J. K. Branickiego. Tutaj 5 pokwitowań hetmana z odebranych przez niego, z racji sprawowania hetmaństwa wielkiego koronnego, należności z kasztelanii krakowskiej i biskupstwa krakowskiego z lat 1763, 1765, 1768-1769,

plik 11

- zestawienia dotyczące kosztów wyekwipowania regimentu w latach 1753-1760. Głównie dotyczą one umundurowania. Tutaj także kontrakt z pończosznikiem na wykonanie pończoch dla żołnierzy regimentu,

plik 12

- zestawienia dotyczące uzbrojenia regimentu z lat 1754-1762. Akta dotyczą reparacji broni oraz zaopatrzenia w amunicję.

plik 13

- akta dotyczące spraw indywidualnych żołnierzy regimentu. Między innymi abszyt i skierowanie do alumnatu inwalidzkiego wystawione przez Klema oraz paszport i prolongacja urlopu dla por. Kruszewskiego wystawiona 1 maja 1771 r. (bez pieczęci i podpisu),

plik 14

- akta spraw spornych i procesowych z udziałem żołnierzy regimentu. Tutaj między innymi znajdują się inkwizycje: w sprawie nieumyślnego zabicia Żyda z 1754 r., w sprawie werbowania żołnierzy regimentu do armii pruskiej, w sprawie kłótni pomiędzy żołnierzami regimentu,

\section{Pudło 11 - Regiment Pieszy Buławy Polnej Koronnej}

plik 1

- regulamin J. K. Branickiego dotyczący organizacji życia finansowego regimentu. Reguluje między innymi kwestie rozłożenia płac, wybierania rat, wydatków na sprzęt i umundurowanie, 
plik 2

- memoriały podane J. K. Branickiemu jako szefowi regimentu przez gen. majora Kampenhauzena, komendanta regimentu w latach 1737-1740, plik 3

- tabele i raporty miesięczne od regimentu i jego poszczególnych pododdziałów z lat: 1735 (luty, październik-grudzień), 1736 (styczeń-wrzesień, listopad), 1737 (styczeń-luty, kwiecień), 1739 (wrzesień-październik), 1741 (grudzień), 1744 (czerwiec, grudzień), 1745 (styczeń-sierpień, wrzesień, listopad-grudzień), 1746 (styczeń-kwiecień), 1748 (czerwiec-wrzesień), 1751 (styczeń-wrzesień).

Raporty nadsyłano z: Białegostoku, Białej Cerkwi, Kamieńca Podolskiego, Lwowa.

plik 4

- zestawienia dotyczące stanu osobowego poszczególnych pododdziałów regimentu. Między innymi rolle żołnierzy stacjonujących w Białymstoku za czerwiec i wrzesień 1739 r. oraz zestawienie wakatów w regimencie z 8 maja 1740 r.,

plik 5

- akta dotyczące spraw finansowych regimentu. Tutaj rachunki przychodu i rozchodu sum wybranych przez poborców regimentowych na rzecz regimentu z województwa lubelskiego i województw wielkopolskich z lat $1748-1751$,

plik 6

- akta finansowe regimentu. Zestawienia (likwidacje) należności regimentu uchwalone przez Trybunał Skarbowy w Radomiu. Łącznie 17 poszytów obejmujących należności za lata 1732-1752, plik 7

- akta finansowe regimentu. Głównie dyspozycje J. K. Branickiego wydane kasie regimentowej w sprawie wypłat wakujących porcji oraz rozliczenia z pisarzem buławy polnej koronnej Markowskim,

plik 8

- akta finansowe regimentu z lat 1739-1751. Przede wszystkim generalne zestawienia wydatków regimentu, w tym również rachunki z kontyngentu J.K. Branickiego,

plik 9

- akta finansowe regimentu z lat 1740-1751. Tutaj głównie pokwitowania od oficerów sztabowych i wyższych z odebranych gaż oraz sum le- 
nungowych (płac żołnierskich) dla poszczególnych kompanii, a także sum na umundurowanie. Dyspozycje Branickiego dotyczące wypłacania wakujących porcji,

plik 10

- akta finansowe regimentu z lat 1736-1752. Między innymi rachunki z regiments-felczerem z lat 1736-1737 (gaża oraz wydatki na zakup lekarstw i sprzętu medycznego), zestawienia związane z reparacją broni oraz wydatkami na zakup umundurowania,

plik 11

- akta dotyczące spraw organizacyjnych regimentu. Kontrakt Klema z pocztmistrzem w sprawie dostarczania i przesyłania korespondencji regimentowej z 1744 r. oraz 2 kontrakty oficerów regimentu w sprawie dostaw sprzętu dla regimentu z lat 1748-1749.

\section{Pudło 12 - Regiment Pieszy Buławy Polnej Koronnej za szefostwa Wa- cława Rzewuskiego}

plik 1

- tabele i raporty miesięczne od regimentu i jego pododdziałów z lat: 1751 (kwiecień-czerwiec), 1752 (sierpień, październik-grudzień), 1753 (styczeń-luty, kwiecień-czerwiec, listopad-grudzień), 1754 (styczeń, marzec, maj-sierpień, październik, grudzień), 1755 (luty, czerwiec, sierpień-grudzień), 1756 (styczeń-kwiecień, czerwiec, sierpień-wrzesień, listopad-grudzień), 1757 (styczeń, kwiecień-maj, sierpień-październik), 1758 (marzec-kwiecień, październik-grudzień), 1759 (styczeń-maj, lipiec), 1760 (styczeń-luty, kwiecień, wrzesień), 1761 (styczeń-luty, kwiecień-maj, wrzesień, grudzień), 1762 (styczeń, marzec-październik), 1763 (luty-kwiecień, czerwiec-lipiec, wrzesień), 1767 (luty, kwiecień-maj, sierpień, listopad), 1768 (styczeń, marzec-lipiec, październik, grudzień), 1769 (luty-październik, grudzień), 1770 (styczeń-luty),

plik 2

- ekstrakt z podanych róll miesięcznych regimentu za czerwiec 1752 r.,

- akta sprawy procesowej dotyczącej sporu pomiędzy rzemieślnikami i handlarzami kamienieckimi a żołnierzami regimentu (inkwizycja i dekret), 
plik 3

- patent na podpułkownikostwo dla A. Kicińskiego z 10 sierpnia 1761 r. - oryginat,

- memoriał gen. majora Kuczyńskiego do J. K. Branickiego w sprawach służbowych z 28 kwietnia 1770 r.,

plik 4

- akta dotyczące głównie spraw finansowych regimentu. Między innymi kwity od regimentu z pobranego pogłównego, z dóbr pozostających w posesji Branickiego w 1762 r.,

plik 5

- akta spraw spornych i sądowych z udziałem żołnierzy regimentu (inkwizycje, dekrety) z lat 1754-1760.

\section{Pudło nr 13 - Regimenty dragonów}

plik 1

- akta administracyjne regimentu dragonów gwardii koronnej. Tutaj między innymi ekstrakty z regulaminu (1749 r.), kopia ordynansu hetmana wlk. kor. J. Potockiego z 7 września 1736 r.,

plik 2

- tabele miesięczne od regimentu dragonów gwardii koronnej z lat: 1753 (kwiecień, lipiec, wrzesień-grudzień), 1754 (styczeń-grudzień), 1755 (styczeń, maj, wrzesień, grudzień), 1756 (styczeń, marzec, lipiec, wrzesień, listopad), 1757 (styczeń, kwiecień, czerwiec-sierpień, październik grudzień), 1758 (marzec, sierpień-listopad), 1759 (styczeń-marzec, wrzesień, listopad), 1760 (luty-kwiecień, listopad-grudzień), 1761 (styczeń-luty, kwiecień-czerwiec, sierpień, październik, grudzień), 1762 (marzec-kwiecień, lipiec, wrzesień październik, grudzień), 1763 (styczeń-wrzesień). Tutaj dodatkowo 1 tabela za maj bez daty rocznej, plik 3

- akta regimentu dragonów gwardii koronnej z 1775 r., plik 4

- akta spraw spornych i procesowych z udziałem żołnierzy regimentu dragonów gwardii koronnej z lat 1753-1759. Między innymi dekrety i inkwizycje,

plik 5

- tabele od regimentu dragonów dowództwa gen. lejtnanta J. Lubomirskiego (za styczeń 1754 r., styczeń i październik 1755 r.), 


\section{Krzysztof Syta}

plik 6

- akta w prywatnej sprawie chor. Szczepanowskiego z regimentu szefostwa gen. lejtnanta J. Lubomirskiego o zaległą gażę z 1752 r., plik 7

- dekret sądu Trybunału Skarbowego w Radomiu w sprawie z udziałem żołnierzy regimentu dragonów J. Lubomirskiego z 1753 r., plik 8

- akta administracyjne regimentu dragonii szefostwa gen. lejtnanta J. Potockiego, a potem gen. lejtnanta A. Sułkowskiego. Był to najprawdopodobniej regiment dragonów Jego Królewskiej Mości. Między innymi ordynanse i zestawienia płac na regiment z lat 1759-1774, plik 9

- tabele i raporty miesięczne od ww. regimentu z lat: 1756 (marzec, październik, 1759 (kwiecień), 1760 (styczeń-marzec), 1761 (luty, czerwiec), 1763 (czerwiec, sierpień), 1767 (luty-maj, wrzesień, listopad), 1768 (styczeń-luty, kwiecień), 1769 (styczeń-luty, kwiecień-maj, lipiec-grudzień), 1770 (styczeń-luty), 171 (marzec, czerwiec-wrzesień),

plik 10

- lista płac lejbkompanii i sztabu ww. regimentu za lata 1759-1760, plik 11

- dekret w sprawie porucznika Jeziorkowskiego z 1773 r., plik 12

- pokwitowanie porucznika Jeziorkowskiego z odbioru pieniędzy w kasie regimentowej z 1777 r.,

plik 13

- akta regimentu dragonów królowej. Tabele i raporty miesięczne z lat: 1749 (sierpień), 1750 (sierpień, grudzień), 1751 (luty-marzec, czerwiec-wrzesień, listopad), 1752 (styczeń-luty), 1753 (styczeń-kwiecień, lipiec-grudzień), 1754 (styczeń-luty, kwiecień, czerwiec-lipiec), 1755 (luty-marzec, sierpień-grudzień), 1756 (styczeń-luty, kwiecień, czerwiec-sierpień, październik), 1757 (kwiecień, czerwiec, sierpień-październik), 1758 (marzec-kwiecień, lipiec-grudzień), 1759 (styczeń, maj, wrzesień-listopad), 1760 (styczeń-luty, kwiecień, wrzesień-październik, grudzień), 1761 (marzec, maj, lipiec, październik, grudzień), 1762 (marzec-lipiec, wrzesień), 1763 (luty-maj), 1767 (ma- 
rzec-maj, grudzień), 1768 (styczeń-luty, grudzień), 1769 (styczeń, marzec-wrzesień, listopad), 1770 (styczeń-luty).

Przypadkowo w pliku tym znajduje się raport od regimentu dragonii królewicza szefostwa płka Fr. Skórzewskiego za wrzesień 1771 r.

plik 14

- lista oficerów ww. regimentu z lat 1754, 1759. Tutaj także 3 ordynanse J. K. Branickiego skierowane do regimentu.

Pudło nr 14 - Regiment Dragonów Najjaśniejszego Królewicza Jegomości (plik 1-4), Regiment Dragonów Buławy Wielkiej Koronnej (plik 5-10) plik 1

- ordynans regimentarza wojsk koronnych J. Potockiego dla regimentu z 17 czerwca1735 r.,

plik 2

- tabele miesięczne od regimentu z lat: 1748 (luty, grudzień), 1749 (styczeń-marzec, wrzesień, listopad), 1750 (styczeń-marzec, maj, lipiec-grudzień), 1751 (styczeń-luty, kwiecień, czerwiec-sierpień, październik-grudzień), 1752 (styczeń-marzec, maj-czerwiec, sierpień), 1753 (grudzień), 1754 (kwiecień), 1755 (za kwiecień), 1756 (kwiecień, czerwiec), 1757 (listopad), 1758 (za październik), 1760 (za sierpień), 1762 (maj), 1767 (luty-maj, wrzesień), 1768 (luty-grudzień), 1769 (luty).

Dodatkowo raport od tego regimentu za wrzesień 1771 r. znajduje się w pudle nr 13, plik 13 .

plik 3

- lista podoficerów regimentu ze stycznia 1754 r.,

plik 4

- ugoda pomiędzy szefem regimentu A. Ossolińskim a jego pułkownikiem Fr. Skórzewskim zatwierdzona przez J. K. Branickiego 12 marca 1754 r.,

plik 5

- kwit poręczycielski dla jednego z oficerów regimentu,

plik 5

- ekstrakt zestawienia płac regimentu ułożony przez Komisję Wojskową z 31 marca 1767 r.,

plik 6

- ordynanse wydawane w latach 1754-1768 przez różnych wojskowych dla regimentu. Między innymi kopie i oryginały ordynansów 
J. K. Branickiego, gen. majora A. Granowskiego, regimentarza partii ukraińskiej i podolskiej F. Ks. Branickiego, Komisji Wojskowej, plik 7

- tabele i raporty miesięczne od regimentu z lat: 1751 (kwiecień, czerwiec-sierpień, październik-grudzień), 1752 (marzec, lipiec-sierpień), 1753 (październik-grudzień), 1754 (styczeń, marzec, maj, lipiec-październik). 1755 (styczeń, kwiecień, sierpień, listopad), 1756 (luty, kwiecień-czerwiec, sierpień-październik, grudzień), 1757 (styczeń, kwiecień-czerwiec, grudzień), 1758 (kwiecień-grudzień), 1759 (styczeń-kwiecień, czerwiec, sierpień), 1760 (luty, czerwiec), 1761 (marzec), 1762 (styczeń, czerwiec), 1763 (maj-lipiec), 1764 (grudzień), 1766 (luty-marzec, maj-lipiec, październik, grudzień), 1767 (styczeń-luty, kwiecień, lipiec-wrzesień), 1768 (styczeń, marzec), 1769 (lutymarzec), 1770 (luty, kwiecień, sierpień, październik), 1771 (maj-czerwiec, sierpień). Ponadto ranglista oficerów z lutego 1770 r. i raport o stanie sztabu regimentu b.d.,

plik 8

- rolla regimentu na dzień 1 czerwca 1751 r. (zestawienie imienne), plik 9

- akta finansowe regimentu. Między innymi specyfikacja wydatków na oficerski mundur oraz asygnacja Komisji Skarbu Koronnego,

plik 10

- akta spraw spornych i procesowych z udziałem żołnierzy regimentu (akty oskarżenia, dekrety sądów itd.).

\section{Pudło nr 15 - Regiment Dragonów Buławy Polnej Koronnej}

plik 1

- zestawienie dyspozycji wydanych regimentowi przez hetmanów: A. M. Sieniawskiego i St. Chomentowskiego (1726 r.), plik 2

- kopie i oryginały ordynansów wydanych regimentowi w latach 1736-1746 przez hetmanów: J. Potockiego i J. K. Branickiego,

plik 3

- memoriały od regimentu do J. K. Branickiego, plik 4

- tabele i raporty miesięczne z lat: 1735 (grudzień), 1736 (styczeń-czerwiec, sierpień-wrzesień, listopad-grudzień), 1737 (styczeń, maj), 
1739 (październik, grudzień), 1747 (grudzień), 1748 (styczeń), 1753 (styczeń-luty, kwiecień, czerwiec-sierpień, listopad-grudzień), 1754 (luty-maj, sierpień-październik), 1755 (sierpień-wrzesień, listopad-grudzień), 1756 (luty, czerwiec, wrzesień), 1757 (marzec-maj, sierpień-wrzesień), 1758 (marzec-kwiecień), 1759 (październik, grudzień), 1760 (marzec-kwiecień, grudzień), 1763 (czerwiec), 1767 (kwiecień), 1768 (grudzień), 1769 (styczeń, kwiecień-maj, lipiec-grudzień), 1770 (styczeń, sierpień), specyfikacja oficerów b.d.,

plik 5

- zestawienia osobowe regimentu z 1736 r., plik 6

- akta finansowe regimentu. Tutaj ordynanse, dyspozycje dotyczące wybierania podatków na rzecz regimentu, akta kasy regimentowej z lat $1735-1746$,

plik 7

- akta spraw spornych i procesowych z udziałem żołnierzy regimentu.

Pudło nr 16 - Regiment dragonów gen. lejtnanta Hieronima Wielopolskiego, koniuszego koronnego

plik 1

- ordynans J. K. Branickiego dla H. Wielopolskiego z 1754 r., plik 2

- tabele miesięczne z lat: 1751 (czerwiec, sierpień, październik-grudzień), 1753 (styczeń, kwiecień-czerwiec, sierpień-grudzień), 1754 (styczeń-maj, lipiec-wrzesień), 1755 (styczeń, sierpień-wrzesień, grudzień), 1756 (styczeń-kwiecień, czerwiec-grudzień), 1757 (kwiecień, czerwiec-wrzesień), 1758 (marzec, czerwiec-lipiec, wrzesień, grudzień), 1759 (marzec, czerwiec-lipiec, wrzesień), 1760 (styczeń-luty, grudzień), 1761 (marzec, maj), 1762 (marzec, maj), 1767 (luty), plik 3

- abszyt dla kapitana I. Potockiego od gen. lejtnanta H. Wielopolskiego z 1767 r.,

plik 4

- akta spraw spornych i procesowych z udziałem żołnierzy regimentu $\mathrm{z}$ lat $1752-1762$, 
plik 5

- akta spraw spornych i procesowych z udziałem żołnierzy regimentu z lat 1761-1762,

plik 6

- tabele i raporty z lat: 1769 (styczeń-luty, czerwiec-listopad), 1770 (styczeń-luty).

\section{Pudło nr 17 - Korpus Artylerii Koronnej}

plik 1

- tabele miesięczne i generalne oraz raporty od Korpusu oraz jego pododdziałów za lata: 1752 (październik), 1753 (styczeń, maj, lipiec-listopad), 1754 (styczeń-marzec, czerwiec, grudzień), 1755 (styczeń, sierpień, grudzień), 1756 (marzec-październik), 1757 (styczeń-luty, kwiecień-maj, lipiec-grudzień), 1758 (marzec-grudzień), 1759 (styczeń-kwiecień, czerwiec, sierpień, październik-listopad), 1760 (styczeń-kwiecień, czerwiec, listopad-grudzień), 1761 (styczeń-luty, kwiecień, czerwiec-sierpień, październik-grudzień), 1762 (styczeń-maj, lipiec-wrzesień), 1763 (marzec-wrzesień),

plik 2

- raporty i rolle pododdziałów Korpusu Artylerii Koronnej z lat 1751-1752 ,

plik 3

- akta finansowe Korpusu, między innymi rachunki dochodów i rozchodów z kwitów kwarcianych na artylerię koronną, z 1738 r.

\section{Pudło nr 18 - oddziały przyboczne J. K. Branickiego}

plik 1

- akta chorągwi piechoty węgierskiej b.p.k. z lat 1736-1770. Przede wszystkim akta o charakterze finansowym, rachunki, zestawienia płac (rolle lenungowe), komputy chorągwi, także raporty. Inkwizycja w sprawie gemejna J. Królewicza z 1762 r.,

plik 2

- akta chorągwi piechoty węgierskiej buławy polnej koronnej z lat 1736-1770, w przeważającej mierze raporty i tabele. Tutaj również akta śledztwa w sprawie dezerterów z chorągwi w 1750 r., 
plik 3

- akta chorągwi janczarskiej b.w.k. z lat 1754-1771. Głównie akta o charakterze finansowym, rolle lenungowe, specyfikacje rachunków, zestawienia wydatków na żołd oraz sprzęt i umundurowanie. Tutaj także akta spraw spornych i procesowych żołnierzy chorągwi, między innymi rozporządzenie testamentowe rotmistrza Konstantego Orchowskiego z 1759 r. oraz akta jego realizacji,

plik 4

- akta orkiestry (kapeli) wojskowej z Białegostoku z lat 1735-1771. Głównie rejestry płac,

plik 5

- akta nadwornej pieszej kompanii węgierskiej z lat 1763-1773. Głównie miesięczne zestawienia płac,

plik 6

- akta finansowe nadwornej chorągwi janczarskiej J. K. Branickiego $\mathrm{z}$ lat 1771-1772. Głównie zestawienia płac, rolle lenungowe,

plik 7

- akta nadwornej chorągwi tatarskiej J. K. Branickiego z lat 1760-1769, zestawienia osobowe (regestry),

plik 12

- akta dotyczące powołania przez województwo podolskie milicji ziemiańskiej z lat 1753-1762. Tutaj także 2 spisy chorągwi milicji z województw: brzeskiego, kijowskiego,

plik 13

- akta finansowe freikompanii chorągwi konnej nadwornej z lat 1766-1772 , głównie rolle lenungowe, regestry.

\section{Pudło nr 19 - akta różnych garnizonów}

plik 1

- akta garnizonu białocerkiewskiego, między innymi rewizja fortecy białocerkiewskiej z 1756 r. oraz tabela garnizonu za maj 1762 r., plik 2

- akta garnizonu białostockiego, między innymi tabele oficerów z maja 1740 r. i kwietnia 1742 r., raporty z hauptwachu (grudzień 1756 r. i 1758 r.), regestry prochu z grudnia 1748 r. i sierpnia 1762 r., 
plik 3

- akta garnizonu buczackiego, tutaj zestawienie płac komendy z kwietnia 1768 r. oraz lista płac żołnierzy b.d.,

plik 5

- akta garnizonu elbląskiego, między innymi: memoriał o stanie fortecy przedstawiony przez gen. majora W. Golza J. K. Branickiemu z czerwca 1751 r. oraz tabele miesięczne od garnizonu elbląskiego z roku 1752 (luty-marzec, czerwiec-sierpień, październik-grudzień) i 1753 (sierpień),

plik 5

- akta cekhauzów z przygranicznych garnizonów: Okopów św. Trójcy, Białej Cerkwi, Kamieńca Podolskiego. Tutaj zbiorcze tabele z 1762 r. (luty-marzec) oraz generalna tabela stanu dział i amunicji z września 1751 r.,

plik 7

- sztamlista oddziału pod komendą Jordowickiego z październik 1757 r., plik 8

- akta garnizonu kamienieckiego. Między innymi regulamin warty ze stycznia 1751 r., projekt zreformowania garnizonu podany przez gen. majora W. Golza (b.d.), memoriał oficerów do komendanta garnizonu w sprawie zaległych gaż z 1745 r.,

plik 9

- akta garnizonu kamienieckiego. Tabele i raporty miesięczne z lat: 1751 (maj-grudzień), 1752 (luty-kwiecień, czerwiec-grudzień), 1753 (lipiec-grudzień), 1754 (marzec-październik), 1755 (styczeń, wrzesień-grudzień), 1756 (styczeń-luty, kwiecień-maj, lipiec-wrzesień, grudzień), 1757 (styczeń, kwiecień-czerwiec, wrzesień, listopad), 1758 (marzec-kwiecień, październik, grudzień), 1759 (styczeń-marzec, maj), 1760 (styczeń-marzec, czerwiec, wrzesień, listopad-grudzień), 1761 (styczeń-luty, kwiecień-maj, grudzień), 1762 (styczeń-marzec, maj, lipiec), 1763 (marzec-kwiecień, lipiec, wrzesień), 1767 (kwiecień-maj, sierpień, listopad-grudzień), 1768 (styczeń-październik, grudzień), 1769 (styczeń-grudzień), 1770 (styczeń-luty),

plik 10

- akta różnych pododdziałów zawierające zestawienia żołnierzy odkomenderowanych ze swoich macierzystych jednostek. Między innymi tabele miesięczne od pododdziału odkomenderowanego do Kamieńca 
z Regimentu Pieszego Najjaśniejszej Królowej (1754 r.), specyfikacje oficerów garnizonu kamienieckiego oraz jego etat z lat 1751-1762, plik 11

- memoriały kierowane na ręce J. K. Branickiego w sprawie renowacji twierdz, między innymi od gen. lejtnanta Potockiego z maja 1757 r. Tutaj także zestawienie dział i moździerzy z twierdzy kamienieckiej b.d.,

plik 12

- meldunek por. Biernowskiego w sprawie epidemii w Chocimiu z listopada 1752 r.,

plik 13

- akta finansowe dotyczące między innymi płac pododdziału Regimentu Pieszego B.P.K. odkomenderowanego do Kamieńca z lutego 1748 r.,

plik 14

- akta spraw spornych i procesowych z udziałem żołnierzy garnizonu i mieszczan kamienickich.

\section{Pudło nr 20 - akta różnych garnizonów}

plik 1

- akta garnizonu stacjonującego w Krakowie. Między innymi zestawienie wydatków na umundurowanie oraz list w sprawie zakwaterowania żołnierzy garnizonu,

plik 2

- akta garnizonu stacjonującego w Lublinie. Ordynans J. K. Branickiego dany 26 grudnia 1754 r. komendantowi garnizonu lubelskiego w sprawie nadużyć żołnierzy w stosunku do Żydów kahału lubelskiego,

plik 3

- akta garnizonu stacjonującego we Lwowie. Tutaj między innymi tabele i raporty od załogi garnizonu lwowskiego (z 25 czerwca 1741 r.) oraz od komendy garnizonu kamienieckiego, dotyczące żołnierzy oddelegowanych do Lwowa: 1751 r. (listopad-grudzień), 1752 r. (styczeń-luty, kwiecień-grudzień), 1753 r. (styczeń-luty, kwiecień, czerwiec-lipiec, wrzesień-listopad), 1754 r. (styczeń, maj, grudzień), 1755 r. (styczeń, sierpień), 1757 r. (marzec-czerwiec, sierpień-wrzesień, listopad-grudzień), 1758 r. (kwiecień-maj). Akta finansowe garnizonu oraz spraw spornych i procesowych z udziałem żołnierzy garnizonu $z$ lat 1752-1762, 
plik 4

- akta garnizonu stacjonującego w Okopach św. Trójcy, plik 5

- akta garnizonu ordynackiego stacjonującego w Ołyce. 3 raporty z grudnia 1755 r.,

plik 6

- akta garnizonu stacjonującego w Poznaniu. Tabele z lat 1751-1752 i b.d. Akta finansowe garnizonu, zestawienie wydatków za okres maj 1750-maj 1751. Akta sprawy procesowej w sprawie tumultu mieszczan poznańskich przeciwko żołnierzom garnizonu poznańskiego b.d., plik 7

- akta cekhauzu warszawskiego. Między innymi raporty miesięczne od załogi cekhauzu z 1751 r. (kwiecień, czerwiec-wrzesień, listopad-grudzień),

plik 8

- akta garnizonu stacjonującego w Zamościu. Między innymi tabele miesięczne z lat: 1752 (styczeń-luty, lipiec, wrzesień-grudzień), 1753 (marzec-czerwiec, sierpień-grudzień), 1754 (styczeń-luty, kwiecień-sierpień, październik, grudzień), 1755 (kwiecień).

pliki n r 8 z pudła nr 18

- akta regimentu pieszego ordynacji ostrogskiej. Między innymi raporty i tabele miesięczne z lat: 1758 (luty-marzec, maj-czerwiec), 1761 (lipiec-sierpień, październik-grudzień), 1762 (marzec-sierpień), 1763 (czerwiec). Zestawienie (komput) płac dla regimentu z 1758 r., akta spraw spornych i procesowych $\mathrm{z}$ udziałem żołnierzy regimentu $\mathrm{z}$ lat $1754-1757$,

plik 9 z pudła n r 18

- akta chorągwi złotej husarskiej pułku ordynacji ostrogskiej. Między innymi dwa memoriały od chorągwi do J. K. Branickiego z 1754 r., rewizja stanu osobowego i sprzętu chorągwi (1757 r.), akta spraw spornych i procesowych z udziałem żołnierzy chorągwi z lat 1754-1757,

plik 10 z pudła n r 18

- akta chorągwi białej pancernej pułku ordynacji ostrogskiej. Rewizja stanu osobowego i sprzętu chorągwi z 1757 r.,

plik 11 z pudła nr 18

- akta korpusu artylerii ordynacji ostrogskiej, 
plik 4 z pudła n r 19

- akta garnizonu stacjonującego w Dubnie. Tutaj między innymi ordynans Janusza Sanguszki do komendanta garnizonu z 1751 r., raporty i tabele miesięczne od garnizonu dubieńskiego z 1754 r. (luty, sierpień-wrzesień, listopad-grudzień), 1755 r. (styczeń-luty, wrzesień, grudzień), 1756 r. (luty-marzec, wrzesień-październik). Raporty z hauptwachu garnizonu o przyjeżdżających i wyjeżdżających z Dubna z 1755 r., inwentarz dział i amunicji znajdujących się w cekhauzie zamku dubieńskiego z $1754 \mathrm{r}$.

\section{Pudło nr 21 - chorągwie husarskie, pancerne i lekkie}

plik 1

- akta dotyczące dystrybuty sum largicjalnych pomiędzy oficerów i towarzyszy chorągwi husarskich i pancernych w 1759 r.,

plik 2

- akta dotyczące chorągwi husarskich. Tutaj między innymi memoriał kompanii chorągwi husarskiej do J. K. Branickiego z 1772 r., ordynanse różnych wojskowych do chorągwi husarskich,

plik 3

- akta chorągwi husarskich. Między innymi regestry chorągwi husarskiej marszałka nadwornego koronnego oraz podkanclerzego litewskiego z maja $1751 \mathrm{r}$. podane regimentarzowi partii podolskiej I. Woroniczowi, sędziemu żytomierskiemu,

plik 4

- akta spraw spornych i procesowych żołnierzy chorągwi husarskich z lat 1754-1761,

plik 5

- akta dotyczące spraw spornych i procesowych z udziałem żołnierzy chorągwi pancernej kasztelana sandomierskiego Ossolińskiego, mieszczanami goniądzkimi i starostą knyszyńskim T. Czapskim z lat 1745-1748 . Sprawa rozpatrywana była przez Trybunał Koronny,

plik 6

- regestry chorągwi pancernych znajdujących się pod Latyczowem z maja $1751 \mathrm{r}$. podane regimentarzowi partii podolskiej I. Woroniczowi, sędziemu żytomierskiemu, 
plik 7

- kopie i oryginały ordynansów J. K. Branickiego wydanych dla żołnierzy z chorągwi pancernych (permisje, egzempty, forsztelacje),

plik 8

- zbiorowe supliki skierowane do J. K. Branickiego od żołnierzy chorągwi pancernych,

plik 9

- akta spraw spornych i procesowych z udziałem żołnierzy chorągwi husarskich i pancernych,

plik 10

- akta chorągwi lekkiego znaku (głównie przedniej straży), między innymi kopie ordynansów, raporty, inkwizycje.

\section{Pudło nr 22 - Partie wojsk}

plik 1

- akta partii wielkopolskiej. Między innymi oblata ordynansu regimentarza partii wielkopolskiej F. Walewskiego, kasztelana rozpierskiego z 1746 r.,

plik 2

- akta partii wielkopolskiej. Między innymi tabele miesięczne z lat: 1767 (marzec-maj, wrzesień i b.d.), 1768 (styczeń-kwiecień),

plik 3

- partia krakowska i sandomierska. Tutaj kopia ordynansu J. Potockiego, hetmana wlk. koronnego do jej regimentarza z 7 września 1736 r., plik 4

- akta partii małopolskiej, między innymi tabele miesięczne z 1767 r. (luty-maj, lipiec, sierpień),

plik 5

- akta partii podolskiej. Tutaj kopia ordynansu J. Potockiego, hetmana wlk. koronnego do jej regimentarza,

plik 6

- akta partii podolskiej. Między innymi kopia ordynansu wojewody kijowskiego S. Potockiego do jej regimentarza, regestr szkód poczynionych przez jedną z chorągwi w starostwie chmielnickim (1751 r.), rewizja posterunków pogranicznych prawego skrzydła partii podolskiej (1761 r.), 
plik 7

- akta partii podolskiej i pokuckiej. Tutaj tabele miesięczne z 1767 r (styczeń, kwiecień, sierpień, grudzień),

plik 8

- akta partii wołyńskiej. Między innymi memoriały podane do J. K. Branickiego, kopie ordynansów, regestry chorągwi, mapa rozlokowania poszczególnych kompanii w roku 1761,

plik 9

- akta partii ukraińskiej. Między innymi akta dotyczące lokacji wojsk partii, tabele z lat 1751-1753, 1755-1756, kopie ordynansów J. K. Branickiego i regimentarzy tej partii z lat 1752-1763, memoriały, petycje, supliki do J. K. Branickiego,

plik 10

- akta partii ukraińskiej. Listy, raporty, relacje i doniesienia komendantów i dowódców poszczególnych oddziałów partii oraz osób cywilnych dotyczące sytuacji w województwach kresowych Rzeczypospolitej,

plik 11

- akta spraw sądowych żołnierzy partii ukraińskiej. Tutaj między innymi inkwizycje i dekrety sądu wojskowego partii ukraińskiej, sądu regimentarskiego, sądu hetmańskiego oraz sądu generalnego wojskowego radomskiego.

\section{AGAD, Zbiory Anny Branickiej - kancelaria hetmańska}

- kopie ordynansów J. K. Branickiego z 1757 r. (sygn. 506, 509),

- memoriał do J. K. Branickiego od Regimentu Pieszego B.W.K. o wydanie niektórych patentów z r. 1760 (sygn. 567),

- instrukcje dane posłom wybranym przez sejmiki przedsejmowe do J. K. Branickiego z lat 1752-1762 (sygn. 1306-1314, 2686),

- projekty dotyczące aukcji wojska (sygn. 2776),

- raporty, tabele i skargi wojskowe (sygn. 2777-2779, 2781-2782, 2784-2786). 


\section{KORESPONDENCJA}

AGAD, Archiwum Roskie - korespondencja pudło nr II, nr bieżący 72-112

- listy od różnych z lat 1732-1770. Między innymi od majora A. von Auspitza (23 sztuki) i podpułkownika Feliksa Bekierskiego (79 sztuk), pudło nr III, nr bieżący 1-60

- listy od różnych z lat 1729-1771. Między innymi od: posła pruskiego Benoit (sztuk 16), pułkownika Biernawskiego (sztuk 19), pułkownika Blocka (sztuk 19), podczaszego płockiego Bromirskiego (185 sztuk), pudło nr IV, nr bieżący 1-76

- listy od różnych z lat 1731-1771. Między innymi od: generała P. T. Czapskiego (sztuk 24), generała ziem ruskich A. Czartoryskiego (sztuk 123), kanclerza wlk. litewskiego M. Czartoryskiego (sztuk 32), pudło $\mathrm{nr} \mathrm{V}$, nr bieżący 1-50

- listy od różnych z lat 1728-1771. Między innymi od: generała Dahlke (sztuk 115), kapitana Dessein (sztuk 22), pułkownika Dortmanna (sztuk 58),

pudło nr VI, nr bieżący 1-76

- listy od różnych z lat 1729-1771. Między innymi od: wojewody malborskiego Działyńskiego (sztuk 11), podskarbiego wlk. litewskiego J. Fleminga (sztuk 21), gen. majora A. Goltza (sztuk 35), pudło nr VII, nr bieżący $1-50$

- listy od różnych z lat 1740-1771. Między innymi od: superintendenta krakowskiego Gordona (sztuk 141), generalnego inspektora wojska koronnego, wojewody rawskiego K. Granowskiego (sztuk 52), pudło nr VIII, nr bieżący 1-85

- listy od różnych z lat 1721-1771. Między innymi od: kasztelana krakowskiego A. Jabłonowskiego (sztuk 40), majora Janiszewskiego (sztuk 40), generała J. Jankowskiego (sztuk 24),

pudło nr IX, nr bieżący 1-67

- listy od różnych z lat 1730-1771. Między innymi od: podpułkownika M. Karbowskiego (sztuk 49), pułkownika Klemma (sztuk 73),

pudło $\mathrm{nr} \mathrm{X}$, nr bieżący 1-18

- listy od różnych z lat 1718-1771. Między innymi od: pułkownika F. Korytowskiego (sztuk 212), podskarbiego ndw. kor. A. Kossowskie- 
go (sztuk 16), podwojewodziego zakroczymskiego Koziebrodzkiego (sztuk 370),

pudło nr XI, nr bieżący 1-66

- listy od różnych z lat 1717-1771. Między innymi od: władz miasta Krakowa (sztuk 16), wojewody chełmińskiego Z. Kretkowskiego (sztuk 26), kasztelana inflanckiego J. Lewickiego (sztuk 95), murgrabiego pałacu warszawskiego Lichomskiego (sztuk 236),

pudło nr XII, nr bieżący 1-49

- listy od różnych z lat 1713-1771. Między innymi od: wojewody lubelskiego, a potem kasztelana krakowskiego A. Lubomirskiego (sztuk 39), gen. lejtnanta T. Lubomirskiego (sztuk 100),

pudło nr XIII, nr bieżący 1-77

- listy od różnych z lat 1729-1771. Między innymi od: prymasa W. Łubieńskiego (sztuk 51), kanclerza kor. J. Małachowskiego (sztuk 25), kasztelana wileńskiego i hetmana polnego litewskiego M. Massalskiego (sztuk 24),

pudło nr XIV, nr bieżący 1-88

- listy od różnych z lat 1719-1771. Między innymi od: marszałka ndw. kor. J. A. Mniszcha (sztuk 57), wojewody mazowieckiego A. Mokronowskiego (sztuk 18), posła D. Ogilvie (sztuk 82),

pudło $\mathrm{nr} \mathrm{XV}$, nr bieżący $1-82$

- listy od różnych z lat 1730-1771. Między innymi od: posła francuskiego de Paulmy (sztuk 14), gen. majora Pflantza (sztuk 102), pułkownika C. de Pircha (sztuk 23),

pudło nr XVI, nr bieżący 1-23

- listy od różnych z lat 1730-1770. Między innymi od: kasztelana krakowskiego S. Poniatowskiego (sztuk 42), generała art. kor. E. Potockiego (sztuk 122), wojewody kijowskiego F. S. Potockiego (sztuk 201), gen. lejtnanta I. Potockiego (sztuk 171),

pudło nr XVII, nr bieżący 1-32

- listy od różnych z lat 1728-1770. Między innymi od: gen. lejtnanta I. Potockiego (sztuk 200), hetmana wlk. kor. i kasztelana krakowskiego J. Potockiego (sztuk 105), podpułkownika Puchalskiego (sztuk 11), pudło nr XVIII, nr bieżący 1-52

- listy od różnych z lat 1738-1771. Między innymi od: hetmana wlk. lit. i wojewody wileńskiego M.K. Radziwiłła (sztuk 128), pułkownika J. de Reinholda (sztuk 122), bankiera Riaucoura (sztuk 34), 
pudło nr XIX, nr bieżący 1-44

- listy od różnych z lat 1729-1771. Między innymi od: gen. lejtnanta Rottermunda (sztuk 138), hetmana pol. kor. W. Rzewuskiego (sztuk 118), hetmana pol. lit. i wojewody połockiego A. Sapiehy (sztuk 18), pudło $\mathrm{nr}$ XX, nr bieżący 1-29

- listy od różnych z lat 1714-1771. Między innymi od: podkanclerzego lit. M. Sapiehy (sztuk 76), wojewody smoleńskiego P. P. Sapiehy (sztuk 66),

pudło nr XXI, nr bieżący 1-59

- listy od różnych z lat 1713-1771. Między innymi od: podskarbiego wlk. kor. K. Sedlnickiego Odrowąża (sztuk 186), pułkownika F. Skórzewskiego (sztuk 44), biskupa krakowskiego K. Sołtyka (sztuk 20), pudło nr XXII, nr bieżący 1-83

- listy od różnych z lat 1724-1771. Między innymi od: pułkownika S. Sutkowskiego (sztuk 16), gen. majora K. W. Szaka (sztuk 23), biskupa płockiego H. Szeptyckiego (17),

pudło nr XXIII, nr bieżący 1-4:

- listy od majora Szuszkowskiego z lat 1752-1768 (sztuk 758), pudło nr XXIV, nr bieżący 1-96

- listy od różnych z lat 1711-1771. Między innymi od: podkomorzego kor. K. Towiańskiego (sztuk 15), koniuszego kor. H. Wielopolskiego (sztuk 91),

pudło nr XXV, nr bieżący 1-41

- listy od różnych z lat 1729-1771. Między innymi od: pułkownika A. Wielowieyskiego (sztuk 30), gen. majora R. Wieniawskiego (sztuk 55), podpułkownika Wiszowatego (sztuk 119), gen. majora J. Witte (sztuk 11),

pudło nr XXVI, nr bieżący 1-79

- listy od różnych z lat 1727-1771. Między innymi od: biskupa krakowskiego A. Załuskiego (sztuk 59), podpułkownika K. Zawoyskiego (sztuk 68), gen. majora M. Zboińskiego (sztuk 42).

AGAD, Archiwum Roskie, suplement do korespondencji, korespondencja Branickich

- listy królewicza polskiego Karola Fryderyka i N.N., oryginały, kopie z lat 1756, 1758, akta luźne (sygn.23). 
AGAD, Zbiory Anny Branickiej - kancelaria hetmańska

- H.Brühl, z lat 1746-1763 (większość sygnatur w obrębie numerów 262-398),

- A. Chrząstowski, gen. major, z lat 1757-1761 (sygn. 736-741),

- L. von Coblenz, z lat 1746-1761 (sygn.1006-1013),

- Ch. Dahlke, pułkownik art. kor., z lat 1733-1763 (sygn. 802-827),

- Fryderyka II, król pruski, z lat 1752-1755 (sygn. 982-993),

- F. Korytowski, pułkownik, z lat 1756-1771 (sygn. 1443-1472),

- W. Łubieński, prymas, (sygn. 1657-1660, 1664-1667, 1670),

- M. Massalski, hetman wlk. lit., z lat 1748-1763 (sygn. 1818-1821),

- J. Mniszech, marszałek ndw. kor., z lat 1753-1768 (sygn. 1893-1900, 1902-1906, 1908-1911),

- A. Mokronowski, generał, z lat 1749-1763 (sygn. 1929-1933, 1935, 1945-1947),

- J. Pflantz, gen. major, z lat 1752-1761 (sygn. 2097-2115),

- J. Potocki, hetman wlk. kor., 23 listy z lat 1736-1738, 1749 (sygn. 2847),

- I. Potocki, gen. lejtnant, 23 listy (sygn. 2850, 2853),

- M. K. Radziwiłła, hetman wlk. lit., 8 listów z lat 1753-1758 (sygn. 2833),

- W. Rzewuski, hetman polny koronny, 5 listów z lat 1750-1763, (sygn. 2963),

- Schutzenberg, pułkownik art. kor., 6 listów z lat 1759-1763 (sygn. 2616),

- K. Odrowąż Sedlnicki, podskarbi wlk. kor., 19 listów z lat 1733-1757 (sygn. 2946),

- M. Woroncow, kanclerz rosyjski, 5 listów z lat 1760-1761(sygn. 2773),

- M. Wodzicki, podkanclerzy kor., 17 listów z lat 1748-1761 (sygn. 2759).

AGAD, Archiwum Radziwiłłów, Dział 4, listy XX. Radziwiłłów

- H. Radziwiłł, chorąży lit., z 1744 r. (t. 12, koperta 129, list 380).

AP Kraków, Archiwum Podhoreckie hr. Andrzeja Potockiego

- August II Sas, (XII, 13/5).

\section{AP Kraków, Zbiory Zygmunta Glogera}

- Kaczyński, pułkownik (sygn. 636),

- Kirym Girej, chan tatarski, z 1760 r.(sygn. 585). 
Biblioteka Uniwersytetu Warszawskiego, Dział Rękopisów

- Bahir Kose Mustafa Pasza, wlk. wezyr (ok. 1764 roku) (sygn. 261).

\section{CPHAU, Kijów, fond 241 Braniccy}

- H. Kostka Rostkowski, 3 listy z 1765 r. (spr. 37, s. 1-4).

\section{KOPIARIUSZE KORESPONDENCJI}

WYCHODZĄCEJ OD J. K. BRANICKIEGO

AGAD, Archiwum Roskie, suplement do korespondencji, korespondencja Branickich

- sygn. 4, z lat 1741, 1752 (2 listy oryginalne, 4 poszyty kopii, 7 kart luźnych),

- sygn. 5, za okres 16.05.1753 r. - 12.02.1754r. (4 poszyty, 7 kart luźnych),

- sygn. 6, za okres 13.02.1754 r. - 12.09.1754 r. (4 poszyty i akta luźne),

- sygn. 7, za okres 12.09.1754 r. -09.04 .1755 r. (4 poszyty),

- sygn. 8, za okres 14.04 .1755 r. -31.12 .1755 r. (4 poszyty),

- sygn. 9, za okres 30.03.1756 r. - 18.08.1756 r. (2 poszyty),

- sygn. 10, za okres 18.08 .1756 r. -31.10 .1756 r. (1 poszyt),

- sygn. 11, za okres 31.10.1756 r. - 19.02.1757 r. (1 poszyt),

- sygn. 12, za okres 06.07.1757 r. - 29.09.1757 r. (1 poszyt),

- sygn. 13, za okres 30.11 .1757 r. -15.02 .1758 r. (1 poszyt),

- sygn. 14, za okres 16.02 .1758 r. -13.05 .1758 r. (1 poszyt),

- sygn. 15, za okres 08.08.1758 r. - 09.12.1758 r. (1 poszyt),

- sygn.16, za okres 17.12.1758 r. - 05.08.1759 r. (1 poszyt),

- sygn. 17, za okres 05.08.1759 r. - 11.12.1759 r. (1 poszyt),

- sygn.18, za okres VIII.1760 r. - X.1760 r. (1 poszyt),

- sygn. 19, za okres 15.07.1762 r. - 09.03.1763 r. (1 poszyt),

- sygn. 20, za okres I, XII.1764 r. - I.1768 r. (akta luźne),

- sygn. 21, za okres 21.04.1766 r. - 19.07.1769 r. (1 poszyt),

- sygn. 22, za okres 24.11.1770 r. - 14.09.1771 r. (1 poszyt).

\section{AGAD, Archiwum Roskie, militaria,}

\section{pudło nr 3}

kopiariusze pism wychodzących z kancelarii wojskowej J. K. Branickiego

- za okres 09.06.1763 r. - 16.06.1764 r. (1 poszyt), 
- za okres 25.11 .1770 r. -21.09 .1771 r. (1 poszyt).

AGAD, Zbiory Anny Branickiej - kancelaria hetmańska

kopiariusze pism wychodzących z kancelarii J. K. Branickiego

- bruliony i pojedyncze kopie listów i innych akt (głównie w obrębie sygnatur 425-607, m.in. sygn. 425-427, 430-433, 440-441, 460-461. Ponadto sygn. $2832-8$ brulionów listów J .K. Branickiego do H. Bruhla.

AKTA OSOBISTE

Archiwum Roskie - prywatno-majątkowe

- akt nominacji na urząd hetmana polnego koronnego z 09.11.1735 r. (sygn. 51, XCVIII 1/8),

- akt nominacji na urząd wojewody krakowskiego z 01.10.1746 r. (sygn. 51, XCVIII 1/20),

- akt nominacji na urząd hetmana wielkiego koronnego z 05.06.1752 r. (sygn. 51, XCVIII 1/27a),

- akt nominacji na urząd kasztelana krakowskiego z 09.11. 1762 r. (sygn. 51, XCVIII 1/48).

AGAD, Zbiory Anny Branickiej - kancelaria hetmańska

- asygnacja wystawiona przez podskarbiego wielkiego koronnego Karola Odrowąża Sedlnickiego dla J. K. Branickiego na b.p.k., Warszawa 31.10.1737 r. (sygn. 467),

- rozkaz, z polecenia króla Augusta III Sasa, wypłacenia przez podskarbiego kor. J. K. Branickiemu należnej sumy (sygn. 1400).

\section{Archiwum Staniseawa Jana Jablonowskiego}

KORESPONDENCJA

AGAD, Zbiory Aleksandra Czołowskiego

- J. Koniecpolski, Rakołupy 05.03.1684 (sygn. 679, s. 20).

AGAD, Archiwum Radziwiłłów, Dział 4, listy XX. Radziwiłłów

- K. S. Radziwiłł, kanclerz lit., z 1697 r. (t.19, kop.233, list 37). 
AGAD, Archiwum Zamoyskich

- Otto Velingk, gubernator Ingrii, Ryga 30.07.1700 r. (sygn. 3031, k. 149-150).

\section{Archiwum Staniseawa Koniecpolskiego}

\section{KORESPONDENCJA}

\section{AGAD, Archiwum Zamoyskich}

- P. Brechwa, podkomorzy wendeński, 08.01.1638 r. (sygn. 2864, s. 71-82),

- J. Bokiej Pieczychwoski, rotmistrz, 10.08.1628 r. (sygn. 2864, s. 63-66),

- Borucki, 28.02.162[?]r. (sygn. 446, mikrofilm nr A-22640, s. 24-26),

- S. Chmielecki, chorąży bracławski, 22.12.1624 r. (sygn. 446, s.41-42),

- M. Doroszeńko, hetman wojska zaporoskiego, 17.02 .1626 r., czerwiec 1626 r. (sygn. 446, s. 31, 35-38),

- W. Kiełczewski, 05.04. 1625 r. (sygn. 3037, s. 147),

- S. Konarski, wojewoda pomorski, 18.11 .1626 r.(sygn. 446, s. 29),

- P. Koniecpolski, rotmistrz, 02.05 .1640 r. (sygn. 2864, s. 93-96),

- Konstanty, burmistrz Ostrowa, 13.11 .1628 r.(sygn. 2900, s.188),

- J. Łowicki, starosta brzeski, 09.06 .1628 r. (sygn. 446, s. 57-58),

- A. Natkowski, rotmistrz, 05.09 .1628 r. (sygn. 446, s. 77),

- S. Oświęcim, 24.12.1638 r.(sygn. 2879, s. 37-38),

- I. Petrytycki, starszy nad wojskiem zaporoskim, 22.03 .1632 r. (sygn. 446, s. 92-93),

- M. Potocki, wojewoda bracławski, hetman pol. kor., 09.12.1645 r. (sygn. 2864, s. 101-104),

- J. Rakoczy, 16.05 .1633 r.(sygn. 2900, s. 190-191),

- A. Slatkowski, rotmistrz, 08.08.1628 r. (sygn. 2900, s.186),

- J. Wężyk, arcybiskup gnieźnieński, 03.09.1628 r. (sygn. 2864, s. 61-62), 31.09.1619 r. i 01.07.1628 r. (sygn. 446, s. 20-22, 65),

- K. Wilczek, 09.09.1628 r. (sygn. 2900, s. 183-184),

- Władysław IV, król polski, 31.10.1644 r. (sygn. 2864, s. 97-100), 28 listów z lat 1635-1643, 1645 (sygn. 3048),

- J. Zadzik, podkanclerzy kor., 01.07.1628 r. (sygn. 446, s. 63),

- J. Zbarazki, kasztelan krakowski, 13.09.1627 r. (sygn. 2864, s. 57-60), 
- J. Zebrzydowski, miecznik kor., 24.11.1627 r. (sygn. 446, s. 39),

- Zygmunt III Waza, król polski, 08.02. i 29.02.1624 r., 30.08 .1628 r. (sygn. 3048, s. 348-351, 367-368). 11 listów z lat 1627-1628 (sygn. 446, s. 44, 46, 48-49, 51, 53, 55, 60-61, 67, 70-71, 73, 130),

- N.N., 05.08.1624 r. (sygn. 2864, s. 55-56),

- N.N., rotmistrz, 09.07 .1628 r. (sygn. 2900, s. 181),

- Rada Miasta Gdańska, 01.09.1628 r. (sygn. 446, s. 75).

\section{AGAD, Archiwum Publiczne Potockich}

- Ferdynand III, cesarz, 18.07.1643 i 15.03 .1644 r. (sygn. 11, k. 6-8),

- Władysław IV, król polski, z lat: 1633 (1 list), 1635 (2 listy), 1636 (5 listów), 1637 (2 listy), 1638 (5 listów), 1639 (5 listów), 1640 (15 listów), 1642 (10 listów), 1643 (6 albo 7 listów), 1644 (10 albo 11 listów), 1645 (7 listów) (sygn. 7, t. 2,).

AGAD, Archiwum Radziwiłłów, Dział 4, listy XX. Radziwiłłów

- J. Radziwiłł, wojewoda wileński, hetman wlk. lit., 1644 r. (t. 16, k. 186, list 248).

\section{AP Kraków, Archiwum Podhoreckie hr. Andrzeja Potockiego}

- G. Luigi, baron de Wolzogen, 05.11.1640 r. (I, 1/33a).

Biblioteka Zakładu Narodowego im. Ossolińskich, Wrocław

- Ferdynanda II, cesarza, 06.01.1629 r. (sygn. 1905/II, k. 6),

- M. Mohyła, wojewoda wołoski, asekuracja z 30.09.1634 r. (sygn. 1905/II, k. 45),

- Wasyl, wojewoda i hospodar ziem mołdawskich, 22.07.1639 r. (sygn. 2576/II, k. 36),

- Władysław IV, król polski, 05.05.1625 r., 30.03.1637 r., 23.03.1640 r., styczeń 1645 r. (sygn. 1925/II, s. 40-41, 56-59, 62-63),

- Zygmunt III Waza, król polski, 05.06 .1623 r., 25.06 .1623 r., 07.08.1623 r., 04.07.1624 r., 10.07.1624 r., 27.07.1624 r., 21.08.1624 r., 11.05.1625 r., 16.01 .1630 r., 01.09 .1629 r.(sygn. 1925/II, s. 24-39, 42-45).

Biblioteka Uniwersytetu Warszawskiego, Dział Rękopisów

- Władysław IV, król polski, 9.02 .1645 r.(sygn. 65, k. 1-2). 


\section{Archiwum Hieronima Augustyna Lubomirskiego}

\section{KORESPONDENCJA}

\section{Biblioteka PAN, Kraków}

- August II Sas, król polski, 16 listów z lat 1702-1706, (sygn. 3741).

Biblioteka Zakładu Narodowego im. Ossolińskich, Wrocław

- August II Sas, król polski, 4 listy (m.in. z 18.06.1702 r. i 08.12 .1704 r.) (sygn. 12046/III, s.29-32, 33-36, 37-40, 41-44).

CPHAU Lwów, Książęta Lubomirscy, fond 835, opis 1

- listy w sprawach prywatnych z lat 1697-1706, (sprawa 1488).

Biblioteka im. Stefanyka, Lwów

- od N.N. (być może hospodara mołdawskiego), w sprawach polityki zagranicznej Turcji, Tatarów, Rosji i Rzeczypospolitej (oba listy z Jass, 11 i 12.04 .1703 r.) - rkps 261, k. 369, 375.

\section{Archiwum Jerzego Sebastiana Lubomirskiego}

\section{KORESPONDENCJA}

AGAD, Archiwum Zamoyskich

- Jan Kazimierz, król polski, 12.06 .1652 r. (sygn. 2868, s. 13),

- S. Koryciński, kanclerz wlk. kor., 09.05.1657 r. (sygn. 1879, s. 33-34).

\section{AP Kraków, Archiwum Sanguszków, teki arabskie}

- K. Czartoryski, bp krakowski, z 1664 r. (teka 282, plik 6),

- Jan Kazimierz, król polski (teka 389, plik 11),

- W. Korwin Gosiewski, hetman pol. lit. (teka 389, plik 11),

- T. Karczewski b.d. (teka 367, plik 10),

- A. Morsztyn, referendarz kor., 48 listów z lat 1660-1664, (teka 247, plik 13), 2 listy z 1661 r.(teka 545, plik 13), z 1663 r. (teka 389, plik 6),

- P. Sapieha, hetman wlk. lit. (teka 389, plik 11),

- P. Sczawiński z 1664 r.(teka 366, plik 13),

- Wojnicki, starosta bielski, z 1661 r. (teka 466, plik 30), 
- list rezydenta elektora brandenburskiego z Elbląga z 1659 r. (teka 282, plik 1),

- list szyfrowany z 1662 r. (teka 282, plik 2),

- list N.N. (po włosku) z Rzymu, z 1662 r. (teka 341, plik 5).

\section{AP Kraków, Archiwum Potockich z Krzeszowic}

- S. H. Lubomirski, starosta spiski, 30.11 .1664 r. (sygn. 3227, XXVIII $1 / 52)$.

\section{AP Łódź, Archiwum Juliana i Kazimierza Bartoszewiczów}

sygn. 13, Korespondencja Jerzego Lubomirskiego, marszałka wlk. kor., het. pol. kor. 1661-1674

- S. Czaplicki z 1662 roku (s. 13),

- J. Grotuski z 1663 roku (s. 8-9),

- J. Leszczyński, kanclerz kor., 5 listów z roku 1666 (w tym jeden bez daty, s. 16-27),

- J. Sokolnicki z 1662 roku (s. 36-37),

- J. Staroski, marszałek koła rycerskiego sejmiku wiszeńskiego, z 1665 roku (s. 39),

- J. Samuel Świderski, marszałek koła rycerskiego, 3 listy z lat 1662-1663 (s. 44, 46, 48).

\section{Biblioteka Zakładu Narodowego im. Ossolinskich, Wrocław} sygn. 6058/II, s. 55-72

- J. Leszczyński, kanclerz kor., 2 listy z lat 1662, 1666,

- P. Ożga, podkomorzy lwowski, z 1665 r.,

- J. Samuel Świderski, marszałek konfederacji wojskowej z 1662 r.,

- J. Wielopolski, starosta biecki, z $1661 \mathrm{r}$.

\section{CPHAU, Lwów, Książęta Lubomirscy, fond nr 835, opis 1}

- W. Korwin Gosiewski, hetman pol. lit., 05.11.1662 r., sprawa 1480.

AKTA OSOBISTE

AP Kraków, Archiwum Sanguszków, teki arabskie

- akta dotyczące konfederacji wojskowej w 1661 r. (teka 466, plik 30), 
- akta dotyczące sprawy elekcji vivente rege w czasach Jana Kazimierza (teka 466, plik 31),

- akt nominacyjny na regimentarstwo z władzą hetmańską z roku 1655, bez daty dziennej (teka 123, plik 5).

CPHAU, Lwów, Książęta Lubomirscy, fond nr 835, opis 1

- akt nominacji na urząd hetmana pol. kor., Częstochowa 03.03.1657 r. (sprawa 1479),

- asekuracja króla Jana Kazimierza wystawiona hetmanom koronnym 12 lipca 1662 r. w Warszawie, w związku z ich prywatnymi wydatkami na potrzeby wojska, (sprawa 1481).

\section{Archiwum Józefa Potockiego}

\section{KORESPONDENCJA}

AGAD, Archiwum Radziwiłłów, Dział 4, listy XX. Radziwiłłów

- H. Radziwiłł, chorąży lit. z 1749 r. (t. 12, koperta 136, list 562).

\section{CPHAU, Kijów, fond nr 49, Potoccy}

- A. Montrym, chorąży, 5 listów z 1746 r. (op. 2, spr. 2178),

- W. Z. Wielogurski, z 1739 r. (op. 2, spr. 1795).

\section{Biblioteka PAN, Kórnik}

- Ibrahim Efendi z 1737 r. (sygn. 1847).

\section{KOPIARIUSZE}

AGAD, Archiwum Roskie - militaria pudło nr 3, plik nr 1-3,

plik 1 - zawiera korespondencję kierowaną do i od Potockiego (oraz innych wojskowych) z lat 1734-1739 i b.d.,

plik 2 - zawiera korespondencję z lat 1736-1740, w liczbie 23 zszywek, plik 3 - zawiera korespondencję z lat 1743-1751. Tutaj także diariusz prac komisji pogranicznej wysłanej nad granicę wołoską z dnia 07.02.1743 r. 


\section{Zbiory Anny Branickiej, kancelaria hetmańska}

- kopie i ekscerpty listów kierowanych do J. Potockiego i odpowiedzi na nie (sygn. 1972-1973, 1988, 2534, 2542, 2641, 2737), między innymi:

- sygn. 1988, Nitosławski, sędzia grodzki kijowski, regimentarz partii ukraińskiej, z 08.03. 1744 r. (s. 1), Leontjow (gen. gubernator kijowski, z 12.02.1744 r. (s. 1-2),

- sygn. 2542, Zaleski, towarzysz husarski znaku kasztelana krakowskiego z 10.08.1738 r. (s. nlb. 2-3),

- sygn. 2641, Mier, major, z 01.07.1737 r. (s. 3-4), Kołczag Seraskier pasza chocimski z 03.06.1737 r. (s. 4-5), Maliński, starosta nowogrodzki, regimentarz partii ukraińskiej, z 01.06.1737 r. (s. 6).

\section{Archiwum Stanisława Rewery Potockiego}

KORESPONDENCJA

AGAD, Archiwum Radziwiłłów, Dział 2 - dokumenty historyczne

- J. Lubomirski, marszałek wlk. kor. z 1657 r.(nr 2229).

\section{Archiwum Seweryna Rzewuskiego}

AKTA OSOBISTE

\section{AP Kraków, Archiwum Podhoreckie hr. Andrzeja Potockiego}

- oryginał i oblaty przywileju dla Seweryna Rzewuskiego na urząd hetmana polnego koronnego (XI 3/17),

- akt nadania buławy polnej koronnej, 08.02.1774 r. (XII, 18/6),

- list przypowiedni na chorągiew pancerną, 08.02.1774 r. (XII, 18/7),

- list przypowiedni na chorągiew husarską, 08.02.1774 r. (XII, 18/8),

- akty nadania orderów Św. Stanisława i Orła Białego z 1775 r. (XII, 18/12-13). 


\section{KOPIARIUSZE}

\section{Archiwum Podhoreckie hr. Andrzeja Potockiego} sygn. X 1/1

- kopiariusz ordynansów, responsów, rezolucji i innych pism wychodzących z kancelarii S. Rzewuskiego za okres luty - czerwiec 1793 r. (łącznie 162 pozycje),

sygn. X 1/1-101

- akta różnych oddziałów wojska koronnego z 1793 r. (poz. 9). Tutaj kopiariusz ordynansów wydanych przez $S$. Rzewuskiego w okresie 18.02.1793-07.04.1793. Między innymi do gen. lejtnanta Lubowickiego, podpułkownika M. Zagórskiego, rotmistrza Tyszkiewicza, pułkownika Hanickiego i gen. majora Złotnickiego.

\section{Archiwum Podhorce II}

sygn. 19

- kopiariusz ordynansów i innych pism wychodzących z kancelarii S. Rzewuskiego z lat 1774-1775. Tutaj także na początku kilka ordynansów wystawionych przez F. K. Branickiego, hetmana wlk. kor., sygn. 111

- kopiariusz wydawanych rozporządzeń wojskowych (ordynanse, paszporty, urlopy, patenty i inne) wychodzących z kancelarii Seweryna Rzewuskiego. Tutaj także rozporządzenia innych osób, np. J. K. Branickiego,

sygn. 365

- kopiariusz wydawanych ordynansów i innych rozporządzeń wojskowych przez S. Rzewuskiego w roku 1793,

sygn. 270

- „Buława wielka y polna Koronna i Wielkiego ks. litewskiego sławna w obozie y w Senacie”. Biografie hetmanów koronnych i litewskich sporządzone głównie w oparciu o prace: Bielskiego, Heidensteina, Kojałowicza, Łubieńskiego, Niesieckiego, Paprockiego, Starowolskiego, Stryjkowskiego, Załuskiego. 
KORESPONDENCJA

\section{AP Kraków, Archiwum Podhoreckie Hr. Andrzeja Potockiego}

- Bezborodkow, hrabia, 3 listy z lat 1791-1794 (XIII, 2/2),

- F. K. Branicki, hetman wlk. kor., 62 listy z lat 1773-1794 (II, 2/3),

- F.A. Bruhl, generał art. kor., 8 listów z lat 1774-1777 (II, 2/8),

- Buczyński, gen. adiutant, 2 listy z lat 1779-1780 (II, 2/9),

- Buhler, baron, 3 listy z 1792 r. (XIII, 2/5),

- A. Byszewski, generał, 1 list z 1773 r. (II, 2/10),

- J. Bzowski, burgrabia krakowski, 4 listy z 1782 r. (II, 2/11),

- D. Cetner, starosta słucki, 1 list z 1780 r. (II, 2/12),

- J. Chodkiewicz, starosta żmudzki, 3 listy z lat 1774-1779 (II, 2/14),

- Corticelli, oficer, 10 listów z lat 1780-1786 (II, 2/18),

- T. Czacki, 2 listy z 1803 r. (XIII, 2/6),

- F. Czapski, 1 list z 1793 r. (XIII, 2/7),

- A. Czartoryski, generał ziem podolskich, 8 listów z lat 1764-1794 (II, 2/21),

- Ch. Dahlke, podpułkownik, 6 listów z lat 1774-1786 (II, 2/24),

- Darowski, 6 listów z lat 1782-1799 (II, 2/25),

- Dzierżanowski, 35 listów z lat 1779 - 1797 (II, 2/28),

- Glasenapp, pułkownik, 1 list z 1792 r. (XIII, 2/10),

- A. Goltz, generał lejtnant, 11 listów z lat 1775-1778 (II, 2/32),

- Karol Habsburg, arcyksiążę, 1 list z 1796 r. (XIII, 2/12),

- Hanicki, pułkownik, 62 listy z lat 1777-1793 (II, 2/35),

- B. Hulewicz, poseł wołyński, 6 listów z lat 1790-1796 (XIII, 2/15),

- Igolstrom, baron, 5 listów z 1793 r. (XIII, 2/16),

- F. Jordan, 33 listy z lat 1788-1791 (II, 2/39),

- F. Karpiński, list z 1784 r. (II, 2/39a),

- M. Kobyłecki, gen. adiutant, 16 listów z lat 1783-1790 (II, 2/41),

- B. Kochowski, 5 listów z lat 1791-1792 (XIII, 2/18),

- A. Komar, 4 listy z lat 1774-1780 (II, 2/42),

- M. Komarzewski, gen. adiutant, 13 listów z lat 1776-1784 (II, 2/45),

- Sz. J. i M. Kossakowscy, 3 listy z lat 1791-1796 (XIII, 2/19),

- J. A. Kraszewski, regimentarz partii wielkopolskiej, 3 listy z 1775 r. (II, 2/56),

- Kurakin, ambasador carski w Wiedniu, 7 listów z lat 1796-1807 (XIII, 2/22), 
- S. Lubomirski, marszałek wlk. kor., 8 listów z lat 1774-1782 (II, 2/61),

- J. Małachowski, kanclerz wlk. kor., z lat 1792-1793 (XIII, 2/28),

- A. Miączyński, generał lejtnant, 6 listów z lat 1792-1794 (XIII, 2/30),

- A. S. Młodziejowski, bp poznański, kanclerz wlk. kor., 4 listy z lat 1773-1779 (II, 2/67),

- J. A. Mniszech, kasztelan krakowski, 5 listów z lat 1774-1777 (II, 2/68),

- M. J. Mniszech, marszałek wlk. kor., 4 listy z lat 1782-1786 (II, 2/69),

- J. Ossoliński, wojewoda podlaski, 4 listy z lat 1775-1781 (II, 2/74),

- P. Ożarowski, generał, 4 listy z lat 1792-1793 (II, 2/76),

- M. J. Pac, gen. lejtnant, marszałek konfederacji barskiej, 19 listów z lat 1773-1784 (II, 2/77),

- S. Piattoli, ksiądz, 4 listy z lat 1787-1789 (II, 2/77a),

- Podhorodeński, brygadier, 17 listów z lat 1774-1789 (II, 2/80),

- Stanisław August Poniatowski, król polski, ok. 20 listów z lat 1774-1793 i b.d. (sygn. XII, 18),

- I. Potocki, marszałek wlk. lit., 10 listów z lat 1775-1788 (II, 2/86),

- S. Szczęsny Potocki, wojewoda ruski, 39 listów z lat 1773-1796 (II, 2/84),

- Przyszychowski, 7 listów z lat 1793-1794 (II, 2/89),

- M. Ryło, bp chełmski, 5 listów z 1779 r. (II, 2/94),

- J. Rzewuski, starosta drohobycki, 5 listów z lat 1778-1792 (II, 2/98),

- J. Rzewuski, porucznik kawalerii narodowej, 3 listy z lat 1783-1786 (II, 2/99),

- W. Rzewuski, hetman wlk. kor., 29 listów z lat 1764-1778 (II, 2/95),

- A. Sapieha, kanclerz wlk. lit., 3 listy z lat 1776-1792 (II, 2/102),

- J. J. de Sievers, ambasador rosyjski, 23 listy z 1793 r. (XIII, 2/48),

- K. Sołtyk, bp krakowski, 6 listów z lat 1767-1782 (II, 2/110),

- J. Sosnowski, hetman pol. lit., 1 list z 1775 r. (II, 2/112),

- J. Stempkowski, wojewoda kijowski, regimentarz, 2 listy z 1775 r. (II, 2/114),

- X. i W. Suchodolscy, 5 listów z lat 1790-1792 (II, 2/115),

- A. Sułkowski, wojewoda kaliski, 3 listy z lat 1776-1778 (II, 2/117),

- F. Sułkowski, gen. lejtnant, 3 listy z lat 1775-1776 (II, 2/118),

- de Vergennes, 5 listów z 1779 r. (II, 2/122),

- W. Węgleński, kasztelan chełmski, 7 listów z lat 1774-1778 (II, 2/125),

- J. Wielhorski, pisarz pol. lit., 7 listów z lat 1776-1794 (II, 2/126), 
- I. Witte, generał, 9 listów z lat 1774-1784 (II, 2/127),

- A. Złotnicki, generał, 3 listy z lat 1792-1793 (II, 2/129).

AKTA ADMINISTRACYJNO-WOJSKOWE

AP Kraków, Archiwum Podhoreckie hr. Andrzeja Potockiego sygn. IV 1/1-247

- akta dotyczące chorągwi piechoty węgierskiej b.p.k. z lat 1774-1793. Tutaj między innymi rolle kwartalne z lat 1774-1775, 1782-1783, raporty miesięczne i powinne $\mathrm{z}$ lat 1775, 1777, 1779, 1783-1786, 1793, regestr starszeństwa z 1775 r. (211), protokół w sprawie nadużyć popełnionych w chorągwi z 1783 r. (233),

sygn. IV 2/2-27

- raporty, sprawozdania, tabele od: regimentu pieszego b.p.k. i jego poszczególnych pododdziałów (z lat: 1774, 1785, 1786), chorągwi węgierskiej b.w.k. z 1775 r., regimentu gwardii pieszej koronnej J.K.M. i Rzeczypospolitej z 1775 r., regimentu dragonii J.K.M. i Rzeczypospolitej z 1775 r., regimentu dragonii b.w.k. z lat 1775, 1777,

- ordynanse różnych wojskowych z lat 1751-1752 (kopie i oryginały) dotyczące regiments kwatermistrza regimentu pieszego b.w.k. A. Grotowskiego,

- tabela dyslokacji wojska koronnego b.d.,

sygn. V 1/1-191

- akta dotyczące regimentu pieszego b.p.k. Tutaj głównie regestry starszeństwa (rang listy) z lat 1774, 1775, 1777-1778, 1782, 1793 (V 1/109-110, 119, 129, 137, 149, 166, 167, 190), rolle kwartalne z roku 1775 (V 1/117, 124), raporty powinne i miesięczne z lat 1774-1775, 1777-1778, 1782-1787, 1790, 1793 (np. V/111-116, 162-165, 187-188), fortragi od regimentu z 1777 roku (np. V 1/130, 132, 134, 140), wypis z protokołu Departamentu Wojskowego w sprawie skargi kapitana Leduchowskiego z 1779 r. (V 1/161).,

sygn. V 2/1-26

- tabele, raporty i sprawozdania od partii (dywizji) małopolskiej z lat: $1775,1777-1779,1789,1793$,

sygn. VI 1/1-165

- akta dotyczące regimentu konnego b.p.k. z lat 1752-1788. Tutaj między innymi raporty miesięczne i powinne od całego regimentu i jego 
poszczególnych szwadronów z lat 1774-1775, 1777-1788 (np. 115-121, 147-152) regestry starszeństwa oficerów sztabowych i wyższych z roku 1775 i b.d. (np. 34, 42, 58), fortragi z lat 1785, 1787-1788 (np. $143,160,162$ ), rolla leibkompanii regimentu z 02.06 .1775 (41), kopie ordynansów wydanych przez hetmanów i Departament Wojskowy Obojga Narodów dla pułkownika regimentu b.p.k. Podhorodeńskiego z 1777 r. (np. 64, 68, 72), kopie ordynansów przesłanych przez gen. majora A. Byszewskiego, dowódcę dywizji małopolskiej, podpułkownikowi Balle z regimentu konnego b.p.k. w roku 1783 (123),

sygn. VI 3/1-22

- raporty miesięczne od: regimentu pieszego artylerii koronnej z 1774 r., korpusu artylerii koronnej z lat 1784, 1785, 1793,

\section{sygn. VII 1/1-94}

- akta z lat 1774-1793 związane z funkcjonowaniem garnizonu w Kamieńcu Podolskim. Między innymi raporty powinne i miesięczne od komendy garnizonu, raporty wydatków na sprzęt, uzbrojenie i fortyfikacje, zestawienia dział i amunicji,

\section{sygn. VII 3-9}

- akta dotyczące różnych oddziałów wojskowych z lat 1774-1794. Tutaj między innymi różnego rodzaju tabele i raporty od: chorągwi husarskiej b.p.k. z 1775 r. (9/4), chorągwi pancernej b.p.k. z roku 1778 i 1783 (9/5-6), pułku przedniej straży województwa krakowskiego z roku 1786 i 1787 (3/1, 4/1), 3 pułku b.p.k. z 1793 r. (4/4-5), 2 i 3 brygady chorągwi kawalerii narodowej z lat 1784, 1790, 1792 (6/1-4), dywizji wołyńskiej i podolskiej z 1793 r. (6/6), garnizonu bielskiego w województwie podlaskim z 1793 r. (6/14), regimentu pieszego łanowego $\mathrm{z}$ lat 1774-1775 (8/3-6),

sygn. VIII 1/1-33

- raporty miesięczne i powinne od regimentów pieszego i konnego dywizji wielkopolskiej z lat: 1775, 1777, 1778, 1779, 1782, 1783, 1784, 1785, sygn. VIII 2/1-33

- raporty miesięczne od regimentu (pułku) J.K.M. i Rzeczypospolitej przedniej straży dywizji małopolskiej z lat: 1775, 1776, 1777, 1778, $1779,1783,1784,1785,1787$,

sygn. VIII 3/1-40

- raporty od dywizji wielkopolskiej z lat: 1775, 1777, 1778, 1785, 1786, 1787, 1788, 1790, 1793, 
- akta dotyczące spraw finansowych poszczególnych pododdziałów dywizji małopolskiej,

\section{sygn. VIII 4/3-57}

- akta dotyczące spraw wojskowych w latach 1792-1794. Między innymi brudnopis i czystopis tekstu przysięgi na wierność konfederacji targowickiej, na czystopisie podpisy sześciu oficerów (4/5-6), wypis z dziennika Konfederacji Generalnej Obojga Narodów z postanowieniem o uprawnieniach hetmanów (4/23), ordynanse Konfederacji Generalnej Obojga Narodów wydane S. Rzewuskiemu, het. pol. kor. (4/24-27, 29-33, 35, 37-39, 41, 43, 48-52), sumariusz dokumentów przekazanych najprawdopodobniej przez S. Rzewuskiego Puławskiemu, marszałkowi Generalnej Konfederacji Koronnej w 1793 r. (4/56), sygn. VIII 5/1-62

- akta dotyczące przede wszystkim dywizji wielkopolskiej z 1793 r. Tutaj głównie raporty powinne od jej dowódcy gen.lejtnanta A. Byszewskiego,

sygn. VIII 6-8

- akta dotyczące fortecy częstochowskiej z lat 1792-1793. Tutaj między innymi raporty powinne (kopie i oryginały) od majora M. Wierzbowskiego, komendanta twierdzy $(6 / 1-4,10,18)$, specyfikacja broni znajdującej się w fortecy częstochowskiej z 20.02.1793 r. (6/6), zlecenie Konfederacji Generalnej dla hetmana pol. kor. S. Rzewuskiego na wydanie ordynansu nakazującego obronę twierdzy częstochowskiej z 05.03.1793 r. (6/12), punkta do kapitulacji fortecy w Częstochowie $(6 / 13-14)$,

- akta dotyczące obrony Krakowa z 1793 r. Między innymi raporty powinne oraz plany obrony Krakowa kierowane do S. Rzewuskiego od: kpt. Gawłowskiego, płk. Sierakowskiego, gen. majora Wodzickiego, gen. P. Ożarowskiego (7/4-6, 9-12, 14, 16),

- raporty powinne od różnych oficerów do S. Rzewuskiego z okresu marzec-kwiecień 1793 r. dotyczące głównie wkroczenia wojsk rosyjskich, sygn. IX 3

- raporty powinne od różnych dowódców kierowane do S. Rzewuskiego w latach 1775-1793 (np. 3/76-79, 94-97). Między innymi tutaj raporty przesyłane do Rzewuskiego w latach 1775-1776 w związku z nieobecnością w kraju hetmana wlk. kor. F.K. Branickiego (np. 
3/51-56). Listy gen.lejtnanta wojska kor. i generalnego inspektora kawalerii narodowej do S. Rzewuskiego z roku 1776 (3/72-73), sygn. X 1/1-101

- akt dotyczące różnych oddziałów wojska koronnego z roku 1793. Między innymi raporty powinne od gen. lejtnanta P. Ożarowskiego, komendanta garnizonu warszawskiego (np. 8, 27, 32, 44, 60), podporucznika M. Zagórskiego z pułku przedniej straży b.p.k. (np. 82, 98), rotmistrza Tyszkiewicza z chorągwi piechoty węgierskiej b.p.k. (np. 13), ekscerpty ordynansów (np. 7, 12, 20, 52), prośby i noty kierowane do $S$. Rzewuskiego w różnych sprawach między innymi przez gen. majora J. Czapskiego o pozwolenie odejścia ze służby (47) i porucznika L. Paszkowskiego o przedłużenie urlopu (23), pokwitowanie gen. majora Brodowskiego z odebranej od S. Rzewuskiego sumy 5.400 złp. za wydatki związane ze służbą (74), dyslokacja dywizji małopolskiej i wielkopolskiej b.d. (101)

\section{Archiwum Staniseawa Mateusza Rzewuskiego}

\section{AKTA OSOBISTE}

\section{AP Kraków, Archiwum Podhorce I}

sygn. 83

- akt nominacji na hetmana polnego koronnego z 05.05.1706 r.,

- akt nominacji na urząd hetmana wielkiego koronnego z 12.10.1726 r.,

- list przypowiedni na regiment pieszy z 26.05.1706 r.,

- list przypowiedni na regiment dragonii z 26.05.1706 r.,

- list przypowiedni na chorągiew husarską z 26.05.1706 r.,

- akt nominacji na urząd wojewody podlaskiego z 02.05.1710 r.,

- akt nominacji na urząd wojewody bełskiego z 14.06.1728 r.

\section{KORESPONDENCJA}

\section{AP Kraków, Archiwum Podhoreckie hr. Andrzeja Potockiego}

- August II Sas, król polski (XII, 13/3),

- J. H. Keyserling, 1 list z 1727 r. (I, 1/45),

- L. Kuczyński, podkomorzy ziemi drohickiej, 1 list z 1717 r. (I, 1/47),

- Maria Kazimiera Sobieska, królowa, 1 list z 1712 r. (XII, 11/2), 
- J. Mazepa, hetman kozacki, 12 listów z lat 1705-1706 (I, 1/48),

- W. Miaskowski, 1 list z 1720 r. (I, 1/48a),

- T. Potocki, prymas, z 1728 r. (I, 1/48b),

- A. M. Sieniawski, hetman wlk. kor., 3 listy z lat 1718, 1722, 1724 (I, 1/50).

\section{AP Kraków, Podhorce I}

sygn. 82

- listy od różnych do S. M. Rzewuskiego z różnych lat.

KOPIARIUSZE

\section{Biblioteka Czartoryskich, Kraków}

sygn. 2448

- kopiariusz zawierający korespondencję wychodzącą głównie z kancelarii hetmańskiej Stanisława Mateusza Rzewuskiego w latach 1721-1722 . Listy pisane głównie do deputatów na trybunał koronny, kanclerza wlk. kor. J. Szembeka, hetmana wlk. kor. A. M. Sieniawskiego, wojewody krakowskiego J. Wiśniowieckiego, cara Piotra I, ambasadora carskiego G. F. Dołgorukiego. Tutaj także ich odpowiedzi.

\section{AKTA ADMINISTRACYJNO-WOJSKOWE}

\section{AP Kraków, Archiwum Podhoreckie hr. Andrzeja Potockiego} sygn. V 1/1-191

- likwidacja regimentu pieszego hetmana pol. kor. S. M. Rzewuskiego dokonana podczas posiedzenia Trybunału Skarbowego w Radomiu w 1723 r. (V 1/2),

\section{sygn. IX 1}

- akta związane z wypłaceniem przez Żydów ostrogskich należności na buławę pol. kor. z 1710 r. (IX, 1/20),

- akta dotyczące wypłaty należności wojskom koronnym (w tym również piechocie węgierskiej hetmana pol. kor.) z lat 1710-1717 (IX, $1 / 20-25)$,

- instrukcja wojskowa na sejm w 1720 r. (IX, 1/36),

- akta sprawy procesowej S. M. Rzewuskiego z J. Przebendowskim, podskarbim wlk. kor. z 1719 r. (między innymi protestacja S. M. Rzewuskiego) (IX, 1/32-33), 
- instrukcja dana posłom Koła Generalnego Wojskowego z 14.11.1716 r. do S. M. Rzewuskiego (IX, 1/26)

- komput wojska koronnego w 1716 r. (IX, 1/27), sygn. XI 1

- akta dotyczące wypłacenia należności na buławę polną koronną. Między innymi asygnacje hetmana wlk. kor. A. M. Sieniawskiego i marszałka konfederackiego S. Denhoffa (XI, 1/5, 9, 11, 12),

- oblata traktatu zawartego ze skonfederowanym wojskiem na sądach generalnych trybunalskich koronnych skarbowych w 1706 r. (XI, 1/4),

- diariusz sejmu grodzieńskiego z 1726 r. (XI, 1/20),

- relacja komisji granicznej między Polską a Śląskiem z lat 1726-1727 (XI, 1/22).

\section{AP Kraków, Archiwum Podhorce II}

\section{sygn. 254}

- „Examen Demonstrativum przeciwko Reglementu Nowego”. Krytyka postanowień wojskowych ustanowionych przez Sejm Niemy, sygn. 256

- Plan reorganizacji wojsk cudzoziemskiego autoramentu i projekt jej przebiegu w latach 1717-1719 wraz z komentarzem, sygn. 263

- „Objaśnienie regulaminu Wojska Pieszego Koronnego 1717 Anni”.

\section{REGULAMINY}

\section{AP Kraków, Archiwum Podhorce II} sygn. 8

- Powinności żołnierskie, postanowienia służby garnizonowej, prawa hetmanów (wypisy z Volumina Legum), artykuły wojskowe, sygn. 38-39

- „Corporis Juris Militaris [...]”. Zbiór regulaminów wojskowych z różnych krajów europejskich,

sygn. 171

- „Inwentarz Artykułów Wojskowych Cudzoziemskich[...]”. Hasła od litery A do B,

sygn. 186

- Regulamin wojskowy. 
AKTA FINANSOWE

\section{AP Kraków, Archiwum Podhorce I}

sygn. 88

- akta dotyczące spraw finansowych różnych oddziałów wojskowych. Większość akt dotyczy spraw związanych z wypłatami należności na mocy postanowień komisji hibernowej lwowskiej i komisji skarbowej radomskiej, między innymi: komputy, specyfikacje zasług, oryginały i kopie asygnacji. Tutaj także akta związane z gratyfikacją urzędu hetmana polnego koronnego,

sygn. 89

- akta dotyczące m.in. płac regimentu pieszego b.w.k. na podstawie specyfikacji z 12.05.1727 r., kopia asygnacji St. Leduchowskiego na pensję b.w.k. (dla Stanisława Mateusza Rzewuskiego), rachunki od regimentu piechoty pod komendą gen. majora J. Kampenhausena po śmierci hetmana wlk. kor. A. Sieniawskiego.

\section{Archiwum Waceawa Rzewuskiego}

AKTA OSOBISTE

\section{AP Kraków, Archiwum Podhoreckie hr. Andrzeja Potockiego} sygn. XII 3-17

- akt nominacyjny na buławę polną koronną, 05.06. 1752 r. (XII, 15/52),

- akt nominacyjny na województwo krakowskie, 18.09. 1762 r. (XII, 15/11),

- akt nadania buławy wielkiej koronnej, 11. 04. 1773 r. (XII, 18/2),

- warunki wynagrodzenia dla hetmana wlk. kor. podpisane przez Stanisława Augusta Poniatowskiego, 23. 04. 1773 r. (XII, 18/3),

- oblata nominacji Wacława Rzewuskiego na urząd hetmana wielkiego koronnego (XI 3/12).

\section{AP Kraków, Archiwum Podhorce I}

sygn. 134

- papiery pozostałe po kapitanie regimentu pieszego b.p.k. A. Grotowskim. Akta zarówno prywatne jak i służbowe. 
sygn. $135-140$

- korespondencja do kapitanów regimentu pieszego b.p.k. A. Grotowskiego i S. Brodowskiego. Najwięcej listów od majora M. Kuczyńskiego z Kamieńca Podolskiego, z lat 1754-1765.

\section{AP Kraków, Archiwum Podhorce II}

sygn. 105

- księga zawierająca informacje dotyczące władzy hetmańskiej w okresie od końca XVI do XVIII wieku sporządzone głównie w oparciu o Volumina Legum. Tutaj także formularze różnych rozporządzeń hetmańskich, np. dekrety sądów hetmańskich różnych hetmanów,

sygn. 50

- księga zawierająca formularze różnych pism, w tym także wojskowych. Między innymi formularze patentów, urlopów, abszytów, egzemptów, pozwów, dekretów (s. 121-157).

\section{KORESPONDENCJA}

AP Kraków, Archiwum Podhoreckie hr. Andrzeja Potockiego

- August II Sas, król, 9 listów z lat (XII/3-17),

- Borawski, 1 list z 1776 r. (I, 1/48c),

- Carocciali, mentor synów Wacława, 1 list z 1756 r. (I, 1/48b),

- A. K. Czartoryski, list b.d. (XIII, 1/4),

- Ch. Dahlke, podpułkownik, 2 listy (I, 1/48e),

- Dębowski, oberstleitnant, 1 list z 1766 r. (I, 1/48f),

- Fryderyk, ks. saski (XII, 17/2),

- Jan Grzegorz, książę mołdawski, 1 list z 1767 r. (I, 1/48l),

- Karol, ks. saski (XII, 17/1),

- I. Krasicki, bp warmiński 1 list z 1767 r. (I, 1/48h),

- Ksawery, ks. saski (XII, 17/3),

- A. Lubomirski, z lat 1754-1755 (I, 1/48i),

- J. Małachowski, kanclerz wlk. kor., z lat 1736-1753 (I, 1/48k),

- P. Ożarowski, gen. lejtnant, z 1776 r. (I, 1/481),

- Stanisław August Poniatowski, król polski, 5 listów z lat 1766, 1773-1774 (XII, 18/1a-c, 4-5),

- A. M. Potocki, 1 list z 1753 r. (I, 1/48n),

- S. Potocki, wojewoda kijowski, 3 listy z lat 1753-1757 (I, 1/48o), 
- Schmidt z 1754 r. (I, 1/49a),

- M. Starzeński, starosta brański, z 1754 r. (I, 1/50a),

- M. Wodzicki, podkanclerzy wlk. kor., z 1754 r. (I, 1/52),

- F. Wołodkowicz, bp chełmski, z 1752 r. (I, 1/53),

- M. Woroncow, hrabia, z 1758 r. (I, 1/54),

- M. Woronicz, z 1757 r. (I, 1/55),

- Zawadzki Bibersztein, z 1753 roku (I, 1/56).

KOPIARIUSZE

\section{AP Kraków, Archiwum Podhorce II}

sygn. 131

- kopiariusz zawierający między innymi korespondencję hetmana z różnymi osobami oraz dyspozycje w sprawach wojskowych,

sygn. 230

- kopiariusz różnego rodzaju dyspozycji wydawanych przez W. Rzewuskiego dotyczących między innymi spraw wojskowych. Tutaj także ordynanse innych hetmanów, np. J. K. Branickiego oraz A. M. Sieniawskiego.

\section{AKTA ADMINISTRACYJNO-WOJSKOWE}

\section{AP Kraków, Archiwum Podhoreckie hr. Andrzeja Potockiego} sygn. IV 1/1-247

- akta chorągwi piechoty węgierskiej b.p.k. z lat 1752-1769. Tutaj przede wszystkim rolle lenungowe chorągwi z lat 1752-1769 (zestawienia miesięczne), raporty miesięczne $\mathrm{z}$ lat 1761-1764, 1768-1769, regestry podszycia butów dla żołnierzy chorągwi z roku 1753 i 1755 $(4,26)$. Tutaj także dwa oryginalne ordynanse W. Rzewuskiego dla chorągwi z lat 1756-1757 (46a, 54a),

sygn. V 1/1-191

- akta dotyczące przede wszystkim regimentu pieszego b.p.k. Tutaj różnego rodzaju sprawozdania, zestawienia i raporty od regimentu. Na przykład rolle kwartalne leibkompanii regimentu z lat 1753 , 1755-1756, 1758-1759, 1761, 1763 (V 1/10, 12-13, 24-25, 27-29, 37, 50, 86), rang i sztam listy z lat 1753, 1760, 1761 (V 1/6e, 8, 40, 51, 103), raporty miesięczne z lat 1752, 1756, 1758, 1760, 1761, 1762, 1763, 1764, 1767 (V 1/6b, 13b, 19a, 20, 41, 42, 53-54, 58-59, 64-65, 
$70,74-75,71,85,87,91-96,98,100,102,105-106)$, oryginały i kopie ordynansów W. Rzewuskiego i innych dla regimentu pieszego z różnych lat (np. V 1/6a, 6c, 9a-b, 13a, 19), dezyderaty kierowane od żołnierzy regimentu do Rzewuskiego (np. V 1/9, 19b, 89, 102c), zaświadczenie od władz miast Buska i Lwowa o właściwym zachowaniu się leibkompanii regimentu w czasie przemarszu z 1759 r. (V 1/23, 26), sygn. VI 1/1-165

- akta dotyczące regimentu konnego b.p.k. z lat 1752-1788. Tutaj między innymi raporty miesięczne i powinne od całego regimentu i jego poszczególnych szwadronów z lat 1758, 1761-1764 (np. 1c, 3, 6, 9, 13) rolle sztabs i oberoficerów z lat 1753, 1761-1764, 1767 (np. 1, 1a, 10, 14, 18), likwidacja regimentu za okres 1.05.1752-30.04.1753 (1b), munster lista od leibkompanii regimentu konnego z 1763 r. (16), kopie rozporządzeń Komisji Wojskowej Wojska Koronnego dane regimentowi konnemu b.p.k. w roku 1767 (26a),

sygn. VI 3/1-22

- tabele od regimentu pieszego artylerii koronnej z 1764 r. (2 sztuki),

- kopie ordynansów różnych wojskowych z lat 1753, 1758-1759, sygn. VII 1/1-94

- akta dotyczące organizacji garnizonu w Kamieńcu Podolskim. Między innymi raporty, etaty oraz dezyderia od garnizonu kamienieckiego z lat 1762, 1764.

sygn. VII 3-9

- akta różnych oddziałów wojskowych. Tutaj między innymi akta lokacji zimowej dla partii ukraińskiej wojska koronnego z 1753 r. (6a-6b), raporty od regimentów pieszych: najjaśniejszej królowej z roku 1762 (7/1), najjaśniejszego królewicza z roku 1764 (7/1a), łanowego $\mathrm{z}$ lat 1762, 1764 (8/1-2). Regestry kompanii chorągwi pancernej hetmana pol. kor. $\mathrm{z}$ lat $1756-1757,1760,1765$ (9/a-c, 1-2),

sygn. IX 1/39

- wykaz chorągwi husarskich i pancernych z 1757 r. (IX, 1/30), sygn. IX 3

- kopie i oryginały ordynansów J. K. Branickiego do różnych wojskowych z 1764 r. (np. 3/32), między innymi ordynans skierowany do wszystkich dowódców wojsk podległych hetmanowi wlk. koronnemu z nakazem poddania się władzy hetmana polnego kor. W. Rzewuskiego z 18.07.1764 r. (3/37). Tutaj także pismo Komisji Rzeczypo- 
spolitej Skarbu Koronnego w odpowiedzi na memoriał W. Rzewuskiego w sprawie wypłacenia należności na buławę polną koronną z 24.10.1771 r. (3/46). Akta dotyczące regimentu pieszego b.p.k. Między innymi ordynans (3/38) oraz akta sprawy o defraudację pieniędzy przez dowódcę regimentu (3/39).

\section{AP Kraków, Archiwum Podhorce II}

sygn. 74

- księga zawierającą głównie postanowienia wojskowe sejmu z 1717. Tutaj repartycja i lokacja zimowa wojska koronnego, regulaminy wojskowe. Likwidacja wojska koronnego na Trybunale Skarbowym Radomskim w 1751 r., regestry poszczególnych chorągwi i regimentów, kopie ordynansów i innych akt hetmańskich,

sygn. 229

- księga regimentu pieszego b.p.k. od roku 1753. Tutaj między innymi rang-i stamlisty, wyciągi z raportów miesięcznych, likwidacje, sprawy finansowe, kopie ordynansów W. Rzewuskiego, regulamin regimentu z 10.02.1753 r.,

sygn. 253

- dziennik raportów hauptwachu w zamku podhoreckim od 29.12.1755 r. do 25.06 .1758 r.,

sygn. 268

- dziennik raportów hauptwachu w zamku podhoreckim od 23.08. 1758 r. do 13.12 .1758 r.,

sygn. 106

- dziennik raportów hauptwachu w zamku podhoreckim od 15.12.1758 r. do 19.03.1760 r.,

sygn. 28

- dziennik raportów hauptwachu $\mathrm{w}$ zamku podhoreckim od 29.08.1762 r. do 23.06.1764 r.,

sygn. 67

- dziennik służby leibkompanii regimentu pieszego b.p.k. za lata 1757-1762 ,

sygn. 83

- księga służby leibkompanii regimentu pieszego b.p.k. Między innymi stamlista leibkompanii sporządzona 01.06.1755 r. (s. 1-21), lista zwerbowanych żołnierzy (s. 31), lista dezerterów z leibkompanii (s. 35). 


\section{REGULAMINY}

\section{AP Kraków, Archiwum Podhorce II}

sygn. 32

_ „Exercitia dragonii w służbie polskiej będącej”. Projekt gen. Hofmana opracowany na zlecenie hetmana wlk. kor. J. K. Branickiego, sygn. 70

- „Pewna partykularna dyspozycja potrzebna do obserwowania u regimentu pieszego buławy polnej koronnej [...]” z 1752 r. Tutaj zbiór formularzy ordynansów, abszytów, urlopów wydawanych w regimencie, tekst przysięgi, regulamin żołnierski i artykuły wojskowe, sygn. 97

- „Tactica sive scientia artis militaris in castris in gua [...] a Joanne de Toux mathematico Illustrissimi nec non Excellntissimi Domini Domini Venceslai in Rozdoł et Rejowiec Rzewuski [...]” z 1752 r. (tekst w języku niemieckim, mapy, plany, szkice),

sygn. 154

- księga zawierająca różne regulaminy wojskowe polskie i obce. Między innymi hetmana wlk. lit. M.K. Paca z 1673 r., króla polskiego Władysława IV Wazy b.d., Stanów Niderlandzkich,

sygn. 250

- regulamin służby wartowniczej w zamku podhoreckim (w języku niemieckim i polskim).

\section{AKTA FINANSOWE}

\section{AP Kraków, Archiwum Podhorce II} sygn. 25

- księga rachunkowa regimentu pieszego b.p.k. za lata 1754-1764. Zawiera zestawienia wydatków i różnego rodzaju specyfikacji związanych z utrzymaniem regimentu, a także kopie listów pisanych w jego sprawach finansowych,

sygn. 36

- księga pokwitowań z pobranych gaż przez oficerów i podoficerów regimentu pieszego b.p.k. z lat 1753-1756, 
sygn. 42

- księga wydatków na utrzymanie leibkompanii regimentu pieszego b.p.k. z lat 1757-1763 (przede wszystkim wydatki związane z umundurowaniem i sprzętem),

sygn. 64

- księga zawierająca rozliczenia dotyczące poboru należności z poszczególnych królewszczyzn na utrzymanie regimentu pieszego b.p.k. z lat $1756-1758$,

sygn. 68

- księga rachunkowa kasy regimentu pieszego b.p.k. Tutaj między innymi ordynanse i inne dyspozycje W. Rzewuskiego jako szefa tego regimentu dotyczące wydatków,

\section{sygn. 81}

- księga lenungowa regimentu pieszego b.p.k. z lat 1753-1756, sygn. 83

- lenung lista leibkompanii regimentu pieszego b.p.k. z lat 1755-1756 (s. 41-62),

sygn. 91

- akta dotyczące zestawienia wydatków na chorągiew (najprawdopodobniej z regimentu konnego W. Rzewuskiego) z roku 1763, sygn. 93

- regulament dla regimentu pieszego b.p.k. wydany przez W. Rzewuskiego w 1756 r. Jest to regulamin dotyczący między innymi prowadzenia spraw finansowych w regimencie. Omawia zagadnienia dotyczące: kasy regimentowej, działalności poborców regimentowych. Ponadto porusza sprawy umundurowania oraz regulamin służby,

sygn. 118

- akta finansowe leibkompanii regimentu pieszego b.p.k. z lat 1756-1760 (rachunki związane z wypłatą żołdu),

sygn. 121

- akta finansowe regimentu pieszego b.w.k. z lat 1756-1765 (rachunki związane z wypłatą żołdu),

sygn. 122

- akta regimentu konnego i pieszego b.p.k. z 1760 r. (jest to zestawienie składów poszczególnych chorągwi i kompanii przygotowane w celu przedłożenia Trybunałowi Skarbowemu w Radomiu), 
sygn. 145

- akta związane z przydziałem płac dla regimentu pieszego b.p.k. w Rawie w roku 1756. Tutaj między innymi etat całego regimentu, wydatki na bron i umundurowanie. W tej księdze również kopiariusz ordynansów i innych rozporządzeń Rzewuskiego, a także korespondencji w sprawach regimentu,

sygn. 229

- księga zawierająca między innymi spraw finansowych regimentu pieszego b.p.k. począwszy od roku 1753.

\section{AKTA JURYSDYKCJI HETMAŃSKIEJ}

\section{AP Kraków, Archiwum Podhorce II}

sygn. 61

- Księga inkwizycji od leibkompanii regimentu pieszego b.p.k. z lat $1755-1762$,

sygn. 260

- przede wszystkim wypisy z ksiąg grodzkich i ziemskich dotyczące spraw spornych z udziałem żołnierzy. Sporo akt z sądu głównego Trybunału Skarbowego Radomskiego.

\section{Archiwum Adama Mikolaja Sieniawskiego}

\section{AKTA OSOBISTE}

Muzeum Narodowe w Krakowie, Biblioteka Czartoryskich sygn. 2624 IV

- między innymi zestawienie wydatków prywatnych hetmana wlk. kor. A. Sieniawskiego na potrzeby publiczne. Wydatki te miały być Sieniawskiemu zwrócone w myśl postanowień sejmu z 1713 roku (s. 1-45),

sygn. $2635 \mathrm{IV}$

- między innymi wysokość pensji, jaka przysługiwała ze skarbu koronnego hetmanowi wielkiemu koronnemu za rok 1725 (s. 177-178). 
AKTA ADMINISTRACYJNO-WOJSKOWE

\section{Muzeum Narodowe w Krakowie, Biblioteka Czartoryskich}

\section{sygn. $2624 \mathrm{IV}$}

- zestawienia wojskowych przystępujących do konfederacji sandomierskiej z ich oryginalnymi podpisami pod rotą przysięgi złożonej między innymi pod Buczniową i Kornilcem 17.10.1710 r. (s. 59-780). Tutaj także kopia ordynansu hetmana wlk. kor. A. Sieniawskiego dla Z. Rybińskiego, wojewody malborskiego i generała artylerii koronnej z grudnia 1714 r. (s. 781-786),

sygn. $2634 \mathrm{IV}$

- akta różne wojskowe z lat 1677-1711. Między innymi: relacje i meldunki żołnierzy z przebiegu działań wojennych, instrukcja dotycząca werbunku (w języku niemieckim), regestry jeńców i zabitych, memoriał łowczego koronnego (najprawdopodobniej Jakuba Zygmunta Rybińskiego) podany A. Sieniawskiemu w sprawach publicznych i wojskowych. Tutaj także sprawy związane z finansami wojska. Większość akt dotyczy wydarzeń z okresu wojny północnej,

\section{sygn. $2635 \mathrm{IV}$}

- akta wojskowe z lat 1712-1788. Między innymi zeznania stronników Karola XII, króla szwedzkiego, wziętych do niewoli i przesłuchiwanych w Brzeżanach w 1712 r., zestawienie jeńców, stronników Leszczyńskiego wziętych do niewoli w 1712 r., relacja uczyniona przez porucznika Kamienieckiego, starostę wieluńskiego, przed Adamem Sieniawskim z przeprowadzonego podjazdu, z 02.09.1712 r., tabela regimentów dragońskich sporządzona przez podskarbiego wlk. kor. J. J. Przebendowskiego we wrześniu 1714 r., desideria wojska koronnego cudzoziemskiego zaciągu przedstawione w Warszawie b.d. Tutaj także akta o charakterze sądowniczym, między innymi sądu oberkrygsrechtowego nad żołnierzem z regimentu pieszego hetmana wlk. kor. z 1723 r. (s.157-158), 
sygn. 2648 IV

- tabele wojskowe z lat 1707-1783. Tutaj między innymi tabele regimentu arkebuzerii hetmana wlk. kor. Sieniawskiego i hetmana pol. kor. S. M. Rzewuskiego z 1708 r. (s. 63, 65) oraz zestawienie ludzi $\mathrm{z}$ różnych regimentów będących pod dowództwem obersterleitnanta Denhoffa w bitwie pod Koniecpolem z dnia 23.11.1708 r.(s. 69). Bardzo dużo tabel z okresu wojny północnej,

sygn. 2883 IV

- akta z lat 1711-1714. Między innymi dziennik nieznanego wojskowego z wydarzeń wojennych z lat 1711-1714, relacje szpiegów z Benderu, wiadomości z różnych miejsc od różnych o wydarzeniach politycznych. Tutaj także korespondencja od podskarbiego nadw. kor. A. Miączyńskiego, wojewody inflanckiego J. M. Kosa, gen. artylerii kor. J. H. Fleminga. Także asygnacje wystawione przez podskarbiego wlk. kor. J. J. Przebendowskiego dla różnych oddziałów, w tym dla regimentu arkebuzerii i regimentu pieszego hetmana wlk. kor. A. Sieniawskiego.

\section{AKTA FINANSOWE}

\section{Muzeum Narodowe w Krakowie, Biblioteka Czartoryskich} sygn. 1684 IV

- między innymi akta związane $\mathrm{z}$ rozdysponowaniem hiberny oraz rachunki wojskowe,

sygn. 2527 IV

- akta zawierające regestry wydatków na utrzymanie służby dworskiej hetmana wlk. kor. A. Sieniawskiego. Między innymi na chorągiew janczarską i kurucką z lat 1712-1721,

sygn. 2557 III

- wyciąg z akt Komisji Hibernowej Lwowskiej z roku 1707. Tutaj między innymi deklaracja Komisji Hibernowej o przyznaniu prawa do wydawania kwitów kwarcianych hetmanowi wlk. kor. A. Sieniawskiego (s. 17),

sygn. $2558 \mathrm{IV}$

- wyciąg z akt Komisji Hibernowej Lwowskiej z lat 1707-1709. W latach 1708-1709 posiedzenia Komisji były limitowane, a jej reasumpcja miała być ogłoszona hetmańskimi uniwersałami, 
sygn. 2565 IV

- ordynanse i asygnacje wydawane przez hetmana wlk. kor. A. Sieniawskiego dla różnych oddziałów, przede wszystkim regimentów i chorągwi b.w.k. (np. dla regimentu pieszego, regimentu dragońskiego i chorągwi piechoty węgierskiej) z lat 1707-1720,

sygn. 2589 IV

- sumariusz zawierający przede wszystkim zestawienia komputów wojska koronnego z lat 1661-1716, spisany w roku 1724, sygn. $2590 \mathrm{IV}$

- zestawienie kwarty wydanej zgodnie z postanowieniami Komisji Hibernowej Lwowskiej w latach 1705, 1707 na podstawie asygnacji hetmana wlk. kor. A. M. Sieniawskiego,

sygn. 2602 III

- akta związane z utrzymaniem piechoty węgierskiej hetmana wlk. kor. A. Sieniawskiego, składającej się z dwóch chorągwi: kuruckiej i janczarskiej. Obejmują listy płac (rolle i lenungi), zestawienia retent, regestry poboru przez żołnierzy butów i umundurowania z lat 1710-1733, sygn. 2606 III

- księga zawierająca różne rachunki w części związane z utrzymaniem regimentu pieszego b.w.k. Głównie są to porachowania z deputatami wysyłanymi od regimentu do różnych ziem w celu ściągnięcia należności,

sygn. 2607 III

- zestawienia sum wydanych przez skarb carski Piotra I na rzecz wojska Rzeczypospolitej w latach 1708-1709,

sygn. 2626 III

- akta finansowe związane głównie z utrzymaniem regimentu pieszego b.w.k. z lat 1710-1715, rolle lenungowe (s. 125-195),

sygn. $2636 \mathrm{IV}$

- akta czynności trybunałów skarbowych i komisji hibernowych odbywanych we Lwowie od końca XVII wieku do roku 1716,

sygn. $2639 \mathrm{IV}$

- akta związane z utrzymaniem różnych oddziałów wojskowych. Między innymi tabele generalne regimentów pieszych królewicza, królowej, hetmana polnego koronnego, hetmana wielkiego koronnego i artylerii koronnej, zawierające wszelkiego rodzaju wydatki związane z ich utrzymaniem (żołd, uzbrojenie, umundurowanie itd.). Spo- 
ro tutaj akt związanych z finansowaniem oddziałów podlegających A. M. Sieniawskiemu, najpierw jako hetmanowi polnemu, a potem wielkiemu koronnemu,

sygn. $2640 \mathrm{IV}$

- akta związane z utrzymaniem wojska. Między innymi repartycja piechoty postanowiona na Walnej Radzie Warszawskiej w 1710 roku, wywód należności z hiberny na pensję buławy wielkiej koronnej z lat $1705-1710$,

sygn. $2641 \mathrm{IV}$

- różne rachunki wojskowe z lat 1711-1715. Między innymi: rozliczenia różnych oddziałów z pobranych sum uchwalonych podczas Walnej Rady Warszawskiej w 1710 r., porachowania z komisarzami hibernowymi, gaże oficerskie piechoty cudzoziemskiego autoramentu z podziałem na regimenty, dokonanym w Gdańsku w 1711 r., zestawienia wydatków ze skarbu koronnego na oddziały przyboczne A. M. Sieniawskiego,

sygn. 2642 IV

- rachunki wojskowe z lat 1714-1720. Tutaj między innymi wykazy dóbr przeznaczonych na utrzymanie chorągwi w 1715 r. (s. 75-86), zestawienia podatków wybranych na utrzymanie chorągwi A. M. Sieniawskego z 1716 r. (s. 89-94), rozdział podatków zebranych w województwie wołyńskim na chorągwie, stacjonujące na Ukrainie, w lutym 1716 r., pensja na buławę wielką koronną wyznaczona postanowieniem traktatu warszawskiego w 1716 r. (s.235),

sygn. $2643 \mathrm{IV}$

- akta dotyczące między innymi spraw finansowych oddziałów podległych bezpośrednio hetmanowi wlk. kor. A. M. Sieniawskiemu oraz jego wynagrodzenia z racji pełnienia urzędu hetmańskiego. Na przykład tabela regimentu pieszego b.w.k. z 1722 r. (s. 60-61) oraz zestawienia należności przypadających na pensję b.w.k. (b.d.),

sygn. 2645 IV

- kwity i asygnacje z lat 1670-1710. Tutaj między innymi asygnacja hetmana wlk. kor. H. A. Lubomirskiego dla oddziału przybocznego hetmana pol. kor. A. M. Sieniawskiego z 1703 r. (s. 189-191), uniwersał hetmana A. M. Sieniawskiego o wypłaceniu przez Żydów na b.w.k. 60 tys. zł. w 1707 r. (s. 349), skrypt pisarza polnego J. I. Lubomir- 
skiego potwierdzający odebranie przez niego z rąk hetmana wlk. kor. A. M. Sieniawskiego należności na dwie chorągwie dragonii (s. 423), sygn. 2646 IV

- akta związane z finansowaniem wojska $\mathrm{z}$ lat 1711-1720. Tutaj przede wszystkim kwity od różnych wojskowych (w tym od deputatów z oddziałów Sieniawskiego) z pobranych gaż i środków rzeczowych, między innymi z dóbr brzeżańskich i garnizonu lwowskiego. Asygnacje różnych wojskowych, w tym hetmana wlk. kor. A. M. Sieniawskiego. Tutaj także asygnacja wystawiona przez podskarbiego wlk. kor. J. J. Przebendowskiego z 1717 r. do Żydów „na pogłówne dla complementum pensji na buławę wlk. Koronną" (s. 423),

sygn. 2647 IV

- asygnacje i różnego rodzaju kwity związane z utrzymaniem wojska. Tutaj między innymi asygnacje wystawiane dla oddziałów podległych hetmanowi wlk. kor. A. M. Sieniawskiemu,

sygn. 2652 IV

- rolle regimentu pieszego najpierw b.p.k. (od czerwca 1702 r. do grudnia 1704 r.) a potem b.w.k. (maj 1706 r.-listopad 1708 r.) - rolle kwartalne. Tutaj na stronie 189 znajdują się polecenia Sieniawskiego w sprawach finansowych z jego podpisem i pieczęcią sygnetową,

sygn. $2653 \mathrm{IV}$

- rolle różnych oddziałów przybocznych hetmana wlk. kor. A. M. Sieniawskiego z lat 1709-1724. Tutaj między innymi rolle od całego regimentu pieszego b.w.k., rolle leibkompanii arkebuzerii, chorągwi janczarskiej, piechoty węgierskiej,

sygn. 2675 III

- księga zawierająca rozliczenia z oddziałami podlegającymi dowództwu hetmana pol. kor. A. M. Sieniawskiego najpierw jako wojewody bełskiego, a później hetmana polnego z lat 1703-1706. Przede wszystkim są to akta kapitulacji z oficerami służącymi w oddziałach Sieniawskiego. Pod niektórymi z tych kapitulacji występują oryginalne podpisy żołnierzy,

sygn. $2700 \mathrm{IV}$

- akta rozdysponowania hiberny dla wojska koronnego, polskiego zaciągu, w latach 1711-1712. Tutaj między innym komput wojska Rzeczypospolitej polskiego i cudzoziemskiego autoramentu ustalony podczas Walnej Rady Warszawskiej w 1710 r., przedstawiony na sejmie 
w $1711 \mathrm{r}$. Rozliczenia z komisarzami, deputatami i innymi podczas Komisji Hibernowej w 1711 r., sygn. 3115 IV

- akta finansowe związane z utrzymaniem regimentu dragońskiego hetmana wlk. kor. A. M. Sieniawskiego, z wyszczególnieniem obciążeń poszczególnych województw, z roku 1717. Tutaj także zestawienie płac na gwardię koronną według nowego regulamentu (najprawdopodobniej z 1717 r.) w języku polskim i niemieckim,

\section{sygn. $3126 \mathrm{IV}$}

- rolle oddziałów przybocznych hetmana wlk. kor. A. M. Sieniawskiego. Z lat 1698-1707 regimentu pieszego wojewody bełskiego, z lat 1710-1712 chorągwi janczarskiej i kuruckiej oraz batalionów regimentu pieszego b.w.k.

\section{AKTA JURYSDYKCJI HETMAŃSKIEJ}

\section{Muzeum Narodowe w Krakowie, Biblioteka Czartoryskich} sygn. 2633 IV

- akta związane z jurysdykcją wojskową, między innymi z okresu hetmaństwa A. M. Sieniawskiego. W przeważającej mierze są to zeznania świadków, sentencje wyroków, apelacje do hetmana A. M. Sieniawskiego (głównie kopie, niewielka część to oryginały).

\section{KORESPONDENCJA}

Muzeum Narodowe w Krakowie, Biblioteka Czartoryskich

- August II Sas, król polski, (ok. 150 listów, w przeważającej mierze w języku francuskim) - sygn. 2734 IV,

- S. Czajka z 1714 roku - sygn. 2747 IV (s. 55-56),

- G. F. Dołgoruki, ambasador carski, z 1717 r. - sygn. 2747 IV (s. 227),

- H. A. Lubomirski, hetman wlk. kor., z lat 1702-1706, 39 sztuk (s. 337-498) - sygn. 2518 IV,

- Piotr I, car rosyjski, 43 listy (większość w języku ruskim, kilka w języku polskim) z lat 1705-1721 - sygn. 2240 IV,

- Wojakowscy (między innymi Kacper i Konstanty) z lat 1714-1715 sygn. 2517 II, 
- podania i supliki od władz miejskich różnych miast (najwięcej z Gdańska, Elbląga, Lwowa, Malborka, Poznania) kierowanych na ręce A. M. Sieniawskiego - sygn. 2574 IV,

- urzędnicy tureccy ( większość w języku tureckim, niektóre przetłumaczone na język polski) - sygn. $2760 \mathrm{IV}$,

- urzędnicy tureccy (listy przede wszystkim w języku tureckim, niektóre z nich przetłumaczone). Adresatami są głównie dowódcy pogranicznych fortec (np. Chocimia). Listy dotyczą między innymi pobytu w Turcji Karola XII i Stanisława Leszczyńskiego - sygn. 2766 IV,

- od różnych z lat 1706-1717. Wśród adresatów występują: starosta żmudzki i hetman pol. lit. H. Ogiński, wojewoda mazowiecki S. Chomentowski, wojewoda malborski T. Działyński, wojewoda malborski P. Kczewski - sygn. 2882 IV.

\section{Muzeum Narodowe w Krakowie, Biblioteka Czartoryskich, Sieniawa}

- J. H. Bartsch, generał, z lat 1712-1715 (167 listów), sygn. 5760 (vol. 5),

- A. S. Bekierski, z lat 1696-1722 (62 listy), sygn. 5761 (vol. 6),

- J. A. Brzuchowski, chorąży halicki, z lat 1707-1716 (67 listy), sygn. 5770 (vol. 15),

- M. Brzuchowski, strażnik pol. kor., z lat 1712-1730 (110 listów), sygn. 5770 (vol. 15),

- Casenare, pułkownik, z lat 1703-1716 (113 listów), sygn. 5773 (vol. 18),

- A. Chrostowski, z lat 1710-1726 (104 listy), sygn. 5777 (vol. 22),

- A. Daszkow, z lat 1701-1716 (68 listów), sygn. 5787 (vol. 32),

- S. Denhoff, hetman pol. lit., z lat 1705-1726 (170 listów), sygn. 5790 (vol. 35),

- A. Derengowski, gen. audytor, z lat 1706-1728 (107 listów), sygn. 5794 (vol. 39),

- G. F. Dołgoruki, ambasador carski, z lat 1709-1720 (35 listów), sygn. 5798 (vol. 43),

- S. J. Fredro, kaszt. lwowski, z lat 1707-1724 (50 listów), sygn. 5811 (vol. 56),

- J. Gałecki, regimentarz, z lat 1714-1717 (87 listów), sygn. 5812 (vol. 57),

- M. Golicyn, książę, z lat 1709-1721 (24 listy), sygn. 5812 (vol. 57),

- de Goltz, baron, z lat 1707-1714 (103 listy), sygn. 5818 (vol. 63),

- Gołowkin, z lat 1702-1719 (119 listy), sygn. 5819 (vol. 64), 
- F. H. Granowski, gen. major, z lat 1695-1730 (63 listy), sygn. 5824 (vol. 69),

- S. Granowski, pułkownik, z lat 1704-1726 (29 listów), sygn. 5825 (vol. 70),

- S. Humiecki, wojewoda podolski, z lat 1697-1736 (231 listów), sygn. 5834 (vol. 79),

- M. Kalinowski, regimentarz, z lat 1706-1728 (142 listy), sygn. 5845 (vol. 90),

- J. J. Kampenchauzen, gen. major, do Sieniawskich i innych z lat 1708-1738 (69 listów), sygn. 5846 (vol. 91),

- P. E. Kczewski, wojewoda malborski, (ponad 340 listów), sygn. 5851-5852 (vol. 96-97),

- A. Kościelski, kapitan, z lat 1714-1718 (34 listy), sygn. 5859 (vol. 104),

- B. Łubieński, gen. major, do Sieniawskich, z lat 1707-1730 (46 listów), sygn. 5880 (vol. 125),

- J. Mazepa, hetman wojska zaporoskiego, z lat 1704-1708 (52 listy), sygn. 5890 (vol. 135),

- Mienszykow, generał carski, z lat 1706-1722 (97 listów), sygn. 5890 (vol. nr 135),

- W. Mier, generał, (109 listów), sygn. 5892 (vol. nr 137),

- L. Pociej, hetman wlk. lit., z lat 1706-1729 (309 listów), sygn. 5961 (vol. nr 161),

- Franciszek II Rakoczy, książę siedmiogrodzki, z lat 1703-1725 (67 listów), sygn. 5929 (vol. nr 174),

- J. Z. Rybickiego, wojewoda chełmiński, gen. art. kor., (ponad 500 listów), sygn. 5937-5938 (vol. nr 182-183),

- S. M. Rzewuski, hetman pol. kor., z lat 1707-1727 (275 sztuk), sygn. 5939 (vol. nr 184),

- B. de Vacquenille, oberst, z lat 1713-1731 (30 listów), sygn. 5762 (vol. 8).

\section{AGAD, Archiwum Zamoyskich}

- J. Mazepa, hetman wojska kozackiego, 02.12 .1707 r. - sygn. 3036 (s. 287-288),

- T. Potocki, prymas, 21.02.1725 r. - sygn. 2892 (s. 117-118). 
SUMARIUSZE

Muzeum Narodowe w Krakowie, Biblioteka Czartoryskich sygn. $2470 \mathrm{IV}$

- sumariusz akt różnych wojskowych z lat 1696-1726.

KOPIARIUSZE

Muzeum Narodowe w Krakowie, Biblioteka Czartoryskich sygn. 2209 IV

- kopiariusz listów głównie do Augusta II Sasa oraz J. H. Fleminga z lat 1717-1719 (korespondencja w języku francuskim), sygn. $2210 \mathrm{IV}$

- kopiariusz korespondencji hetmana A. M. Sieniawskiego z różnymi, z lat 1713-1716 (w języku francuskim),

sygn. 2804 IV

- kopiariusz korespondencji hetmana A. M. Sieniawskiego z różnymi z lat 1708-1713.

\section{Archiwum Mikolaja Hieronima Sieniawskiego}

AKTA OSOBISTE

Muzeum Narodowe w Krakowie, Biblioteka Czartoryskich sygn. $2645 \mathrm{IV}$

- kwity i asygnacje 1670-1710. Tutaj deklaracja hetmana wlk. kor. S. J. Jabłonowskiego z roku 1683 określająca, z jakich dóbr pobierane być mają podatki na pensję buławy polnej koronnej w wysokości 40 tys. zł. pol. (s. 79-80).

KORESPONDENCJA

Muzeum Narodowe w Krakowie, Biblioteka Czartoryskich

- Jan III Sobieski, król polski, z 1683 roku, sygn. 2757 IV, (13 sztuk),

- H. A. Lubomirski, chorąży wlk. koronny, z 22.01.1683 r., sygn. 2518 IV (s. 71). 


\section{Archiwum Jana Sobieskiego}

\section{AGAD, Archiwum Radziwiłłów, Dział 10,}

Wśród archiwaliów działu 10 Archiwum Radziwiłłów znajdują się archiwalia różnych rodzin, w tym również Sobieskich. Tutaj między innymi akt nominacji Jana Sobieskiego na hetmana wielkiego koronnego, listy do Jana Sobieskiego od kahału lwowskiego z okresu hetmańskiego (pudło nr 15) oraz zestawienie wydatków Jana Sobieskiego począwszy od dnia 29 kwietnia 1671 r. do maja 1672 r. Tutaj wiele wydatków na poselstwa obce i krajowe. (Sobiescy, Jan III, pudło nr 61).

\section{KORESPONDENCJA}

AGAD, Archiwum Radziwiłłów, Dział 2 - dokumenty historyczne

- M. Oborski z 28.02.1672 r. (nr 2800),

- Krzysztof Pac, kanclerz lit., i inni senatorowie z 08.09.1672 r. (nr 2862).

AGAD, Archiwum Zamoyskich

- A. K. Grudziński, wojewoda poznański, b.d. (sygn. 3054, s. 9).

Biblioteka Zakładu Narodowego im. Ossolińskich, Wrocław

- Jan Kazimierz Waza, król polski z Warszawy 30.03.1667 r. oraz dwa listy b.d. (sygn. 12046/III, s. 19-20, 29-36).

\section{Archiwum Jana Tarnowskiego}

\section{AKTA OSOBISTE}

\section{AP. Kraków, Archiwum Sanguszków}

- Zygmunt I, król polski, nadaje Janowi Tarnowskiemu, wojewodzie ruskiemu i hetmanowi koronnemu 15 wsi na Pokuciu po zdrajcach, którzy przeszli na stronę wojewody mołdawskiego, Piotrków 3 stycznia 1531 roku, nr 171,

- Zygmunt I, król polski, nadaje Janowi Tarnowskiemu, hetmanowi koronnemu wszelki ruchomy i nieruchomy majątek po zmarłym we Lwowie Hanuszu Puszkarzu, Kraków 16 lutego 1532 roku, nr 173, 
- Zygmunt I, król polski, udziela Janowi Tarnowskiemu pełnomocnictwa do układania się i zawarcia pokoju z posłami hospodara wołoskiego, Kraków 4 lipca 1538 roku, nr 197,

- Zygmunt I, król polski, nadaje Janowi Tarnowskiemu, hetmanowi wlk. kor. za zasługi wojenne przeciwko Wołoszy dobra Gaje i Wodniki, położone w ziemi lwowskiej, Wilno 3 lipca 1540 roku, nr 207,

- Zygmunt I, król polski, pozwala Janowi Tarnowskiemu, kasztelanowi krakowskiemu i hetmanowi wlk. kor. udać się za granicę, zwalniając go z od wszelkich zajęć i obowiązków publicznych, wynikających z jego urzędów i godności, Kraków 17 maja 1543 roku,

- Zygmunt August, król polski, potwierdza Janowi Tarnowskiemu, kasztelanowi krakowskiemu i hetmanowi wlk. kor. wszelkie prawa i przywileje nadane przez poprzednich królów jemu i jego przodkom, Piotrków 21 stycznia 1549 roku, nr 237.

\section{Archiwum Jana Zamoyskiego}

KORESPONDENCJA

\section{AGAD, Archiwum Zamoyskich}

- S. Cikowski, podkomorzy krakowski, z lat 1599, 1602, 2 listy (sygn. 172),

- J. K. i H. Chodkiewiczowie, z lat 1602-1604, 8 listów, (sygn. 171),

- M. i J. Daniłowiczowie, z lat 1599-1604, 5 listów (sygn. 174),

- J. Farensbach, wojewoda wendeński, z lat 1598-1601 i b.d., 15 listów (sygn. 178),

- M., J. i A. Firleje, z lat 1593-1604, 42 listy, (sygn. 179),

- M., J. Sz., J. i A. Herburtowie, z lat 1590-1604, (sygn. 190),

- M. Jazłowiecki, starosta śniatyński, z lat 1585-1594, 3 listy, (sygn. 193),

- M. i Z. Kazanowscy, z lat 1579, 1602, 2 listy (sygn. 196),

- A., J., M. i S. Łaszczowie, z lat 1584-1604, 6 listów (sygn. 210),

- H. i M. Mieleccy, z lat 1577, 1594, 2 listy (sygn. 213),

- J. i J. Mniszchowie, z lat 1572-1604, 10 listów (sygn. 214),

- S. Otrębus, rotmistrz, z 06.04.1601r. (sygn. 275),

- J., K. i A. Ostrogscy, z lat 1593-1604, b.d., 34 listy (sygn. 222),

- A., J., J. i M. Potoccy, z lat 1591-1604, 18 listów (sygn. 228),

- J. Pretficz, kasztelan kamieniecki, z lat 1594-1599, 4 listy (sygn. 229), 
- H. Ramel, rotmistrz, z 28.08.1601 r. (sygn. 134),

- Z. Rosen, z 18.03.1582 r. (sygn. 134),

- J. Serny z 29.03.1602 r. (sygn. 275),

- M. i S. Sobiescy, z lat 1593-1604, 17 listów (sygn. 245),

- Stefan Batory, król polski, z lat 1581-1585, 10 listów, (sygn. 141),

- J. Tarnowski, rotmistrz, z lat 1596, 1601, 2 listy(sygn. 253),

- S. Tarnowski, chorąży sanocki, z 18.05. 1601 r. (sygn. 275),

- M. i W. Uhrowieccy, z lat 1578-1604 i b.d., 6 listów (sygn. 258),

- A. i M. Wiśniowieccy, z lat 1590-1603, 6 listów (sygn. 262),

- S. Włodek, wojewoda bełski, z lat 1593-1603, 8 listów (sygn. 263),

- J. Zachorowski, rotmistrz, b.d., 2 listy (sygn. 268),

- J. i S. Zbarascy, z lat 1581-1600, b.d., 12 listów (sygn. 270),

- Zygmunt III Waza, król polski, z lat 1587, 1590-1591, 1593-1604, 70 listów (sygn. 142),

- S. Żółkiewski, hetman pol. kor., z lat 1584-1604, 48 listów (sygn. 273),

- Kozacy Zaporoscy, z lat 1593-1603 i b.d., 8 listów(sygn. 153),

- od różnych m.in. w sprawach wojskowych z lat 1578-1603, 32 listy (sygn. 275),

- od różnych (sygn. 134, w sprawach wojskowych między innymi od Z. Rosena z Gdańska 18.03.1582 r., od B. Ostrowieckiego z Kwissy 30.07.1592 r., zbiorowy od rotmistrzów i towarzyszy z 19.06.1602 r., od rotmistrza T. Dąbrowskiego z 1603 r.).

\section{AGAD, Archiwum Publiczne Potockich}

- Stefan Batory, król polski, z 11.12.1580 r. (sygn. 7, t. 1, s. 45),

- Zygmunt III, król polski, z 17.08.1601 r. (sygn. 9, t. 1, s. 69-70).

\section{AGAD, Archiwum Radziwiłłów, Dział 4, listy XX. Radziwiłłów}

- Krzysztof „Piorun” Radziwiłł, hetman wlk. lit., (t. 22, kop. 293, list 132 i 134, 147, kop. 294, list 163).

\section{Biblioteka Uniwersytetu Jagiellońskiego}

sygn. 7029 IV

- J. Farensbach, z 1595 r.,

- J. Pretwicz, kasztelan kamieniecki, z 1600 r.,

- Zofia z Ocieszyna, kasztelanowa sandomierska. 


\section{Biblioteka Zakładu Narodowego im Ossolińskich, Wrocław}

- Maksymilian II, cesarz, z 1575 r. (sygn. 1904/II, s. 1-2),

- Stefan Batory, król polski, z 1582 r. (sygn. 1904/II, k. 4-7), 22.01 .1584 r. (sygn. 1925/II, k. 14-15),

- Zygmunt III Waza, król polski, 18.01.1602 r. (sygn. 1925/II, k. 20-21).

KOPIARIUSZE I KOPIE

\section{AGAD Archiwum Zamoyskich}

sygn. 40

- między innymi terminaty pism wychodzących z kancelarii J. Zamoyskiego, s. 171-179, 217-218,

sygn. 128

- między innymi do Pontusa de la Gardie, dowódcy wojsk szwedzkich, z 1582 r. (s. 5-6), szlachty wołyńskiej z 1590 r. (s. 13-16), wojewody sandomierskiego J. Mniszcha z 10.02.1594 r. (s. 112-114), hetmana pol. kor. S. Żółkiewskiego z 1595 r. (s. 149),

sygn. 280

- kopiariusz wysyłanej i odbieranej korespondencji J. Zamoyskiego z lat 1581-1582,

sygn. 754

- terminaty pism wysyłanych z kancelarii Zamoyskiego. Między innymi do wojewody lubelskiego M. Zebrzydowskiego z 31.07.1592 r., s. 3-6, do króla polskiego Zygmunta III z Turobina 16.08.1603 r., s. 17.,

sygn. 866

- brudnopisy listów J. Zamoyskiego do hetmana pol. kor. S. Żółkiewskiego,

sygn. 3112

- między innymi spis listów wysłanych z kancelarii Zamoyskiego 2[?] kwietnia 1602 r., k. 112.

AKTA ADMINISTRACYJNO-WOJSKOWE

\section{AGAD, Archiwum Zamoyskich}

sygn. 38

- regestry, zestawienia, spisy wydatków na wojsko, żołnierzy, sprzęt. Między innymi regestr roty strażnika koronnego z 1.11 .1600 r. (s. 38-39), lista puszkarzy zaciągniętych na wyprawę inflancką w Gdańsku 
31.07.1601 r. (s. 87), lista dezerterów spod Białego Kamienia b.d. (s. 90-93),

- rozkazy, uniwersały, petycje. Między innymi polecenie hetmana dotyczące rozdawania leż z 1581 r. (s. 27-28), petycja hetmana pol. kor. S. Żółkiewskiego i rycerstwa do króla b.d. (s. 40-41), kopie ordynansów J. Zamoyskiego (s. 52-54), fragment artykułów wojennych J. Zamoyskiego b.d. (s. 63-64), kopia instrukcji dla komornika M. Moszyńskiego w sprawie wypłaty żołdu żołnierzom z 07.11.1601r.,

- rachunki, kwity. Kwit dany pisarzowi skarbu koronnego od podstarościego na wyprawę dla J. Zamoyskiego z 20.07.1598 r. (kopia uwierzytelniona), kwit z $1601 \mathrm{r}$. z pobranych pieniędzy dla J. Zamoyskiego, zestawienie wydatków na wojnę inflancką z 1601 roku (s. 80-84),

sygn. 128

- artykuły żołnierskie opracowane przez J. Zamoyskiego (s. 198-210), sygn. 2775

- wynagrodzenie żołnierzy hetmańskich w latach 1582, 1584 (s. 1-6), sygn. 3112

- między innymi kopia uniwersału hetmana pol. kor. S. Żółkiewskiego b.d., (k. 61), kopia listu J. Zamoyskiego do rotmistrzów z 05.07.1597 r. (k. 62-63),

- regestry, zestawienia, spisy wydatków wojskowych, żołnierzy i sprzętu, raporty. Między innymi: regestr roty J. Horwatha pod Pskowem z 30.08.1582 r. (k. 21-22), regestr roty pieszej w obozie pod Dniestrem nieopodal Halicza z 1.11 .1596 r. (k. 59), spis armaty w Derpnie z 25.09.1588 r. (k. 37-38), regestr armaty jaką Moskwa ma wywieźć z Inflant po zawarciu pokoju, przełom 1581/1582 r. (k. 23-31), stan załogi derpskiej z lat 80. XVI w. (k. 39-42), wydatki na wojsko, tzw. koszt doroczni (k. 49), regestr szkód poczynionych przez rotę Daniłowicza stacjonującą w Czernichowie z 1596 r. (k. 57-60), regestr rotmistrzów z ok. 1600 r. (k. 68-71), regestr rotmistrzów z podliczeniem sumy żołdu za pół roku z 1601 r. (k. 72-77) regestr sołdatów, którzy mieli ćwiczyć piechotę (k. 78), regestr roty kanclerza kor. J. Zamoyskiego (k. 80), spisy rot w Inflantach (k. 108-111). 
AKTA JURYSDYKCJI HETMAŃSKIEJ

AGAD, Archiwum Zamoyskich

sygn. 2902

- akta z przesłuchania świadków w sprawie pojedynku pomiędzy towarzyszami Witosławskim a Chynowskim, podpisane przez rotmistrza J. Szczęsnego Herburta z Fulsztyna i porucznika jego roty S. Tarnowskiego z 04.10.1594 r. (s. 46-51).

\section{Archiwum StanisŁaWa ŻóŁKIEWSKiego}

AKTA OSOBISTE

\section{AGAD, Archiwum Radziwiłłów, Dział I}

- nominacja na urząd hetman pol. kor., Lublin 7 listopada 1588 roku (sygn. 774/18, Zbiór dokumentów pergaminowych AGAD, nr 7943),

- nominacja na urząd hetmana wlk. kor., Warszawa 6 lutego 1618 roku (sygn. 926/138, Zbiór dokumentów pergaminowych AGAD, nr 8133),

\section{AGAD, Archiwum Radziwiłłów, Dział X}

pudło 62 - przywilej Zygmunta III dla Stanisława Żółkiewskiego na wieś Turzynkę, Warszawa 31.03.1616 r.

KORESPONDENCJA

\section{AGAD, Zbiory Aleksandra Czołowskiego}

sygn. 435, nr mikrofilmu A-39042

- W. Goślicki, bp przemyski, 02.01.1599 r. (s. 89-91).

\section{AGAD, Archiwum Zamoyskich}

sygn. 3028

- J. Mohyła, hospodar mołdawski, Romanów 10.11.1599 r. (k. 180),

- burkułab suczawski i hetman wołoski, Suczawa 1600 r. (k. 75-76), sygn. 3036

- J. Zbaraski, wojewoda bracławski, Krzemieniec 24.02.1593 r. (s. 329), 


\section{sygn. 3048}

- Zygmunt III Waza, król polski, Kraków 28.04.1609 r. (s. 333-335).

Krzysztof Syta

Resources for the User's Guide to the Royal Hetman's Archives in archives and library collections

Su m m a ry:

This article is an overview of archival collections with provenance of hetman's archives, but physically separated into collections in archives and libraries across Poland (Krakow, Kornik, Lodz, Poznan, Warsaw) and also Ukraine (Kiev, Lviv). Research, which later became an inspiration for this overview, has been conducted mainly in the early '90s. In the light of the above, this article does not claim to be called a 'guide' to the royal hetmans' archives of the sixteenth through to the eighteenth century, but it could be viewed as an outline of such archival finding aid. This overview focuses on characteristics of different types of archival material, which author considered integrally connected to holding of an office of hetman, i.e.: personal, administrative and military, judiciary, financial, and also correspondence. Qualification criteria may raise some concerns, because selection of archives is subjective by nature, but also because in the discussed time period there was social consensus on the fact that one's private life and public sphere would overlap. Most of the archival materials used in this study comes from the hetman's archives of the eighteenth century (Jan Clement Branicki's; Franciszek Ksawery Branicki's; Stanisław Mateusz, Wacław, Seweryn Rzewuski's; and Adam Mikołaj Sieniawski's). Eighteen century is considered to be the peak of development of private archives, which - without a doubt - had great impact on the preservation of hetman's archives of that period. Moreover, the fact that there is significantly larger collection of hetman's archives of that period, compared to previous two centuries, is the result of the hetman's office having a special place within the political system of the Polish-Lithuanian Commonwealth. 